\title{
O Novo Modelo de Constitucionalismo da COMUNIDADE BRITÂNICA ${ }^{1-2}$
}

\author{
Stephen Gardbaum ${ }^{\circledR} *$
}

\begin{abstract}
1 Introdução. $2 \mathrm{O}$ modelo norte-americano de constitucionalismo e sua ampla adoção após 1945. 3 As três declarações de direitos e garantias da Comunidade Britânica. 3.1 A carta de direitos e liberdades canadense de 1982. 3.2 A lei de declaração de direitos da Nova Zelândia de 1990. 3.3 A lei de direitos humanos do Reino Unido de 1998. 4 Avaliação do modelo de constitucionalismo da comunidade britânica. 4.1 A natureza do novo modelo. 4.2 Comparação entre os modelos de constitucionalismo da Comunidade Britânica e dos Estados Unidos. 4.2.1 Os benefícios potenciais do novo modelo. 4.2.2 Esses benefícios podem ser alcançados sem que se rejeite o modelo norte-americano? 4.2.3 O impacto do novo modelo sobre as soluções existente para o problema do judicial review. 4.3 Qual das três versões do modelo da comunidade britânica tem maior probabilidade de proporcionar seus benefícios distintivos?. 5 Conclusão. Referências.
\end{abstract}

\section{RESUMO}

O "novo modelo de constitucionalismo da Comunidade Britânica" se refere a uma estrutura ou abordagem geral comum subjacente às cartas de direitos introduzidas no Canadá (1982), Nova Zelândia (1990) e Reino Unido (1998). Como um experimento recente e contínuo em design constitucional, o novo modelo da Comunidade Britânica pode ser algo inédito. Ele representa uma terceira abordagem à estruturação e institucionalização de disposições constitucionais básicas que ocupa o ponto intermediário entre as duas tradicionais opções de supremacia legislativa e judicial, que se excluíam mutuamente. Ele também provê técnicas novas e - pode-se argumentar - melhores para proteger direitos dentro de uma democracia por meio da realocação de poderes entre cortes e legislaturas, o que estabelece maior equilíbrio que qualquer desses dois modelos assimétricos. Dessa forma, o novo modelo da Comunidade Britânica promete ser para os modelos de constitucionalismo o que a economia mista é para formas de organização econômica: uma terceira via distinta e atraente, entre dois extremos mais puros, porém falhos.

Palavras-chave: Controle Judicial Fraco de Constitucionalidade (Weak-form Judicial Review). Supremacia Judicial. Constitucionalismo Democrático. Anulação Lesgislativa. Lei de Direitos Humanos do Reino Unido.

\footnotetext{
* Stephen Gardbaum é Professor de Direito da Faculdade de Direito da Universidade da Califórnia, em Los
} Angeles (UCLA).E-mail: <gardbaum@law.ucla.edu>. 


\section{INTRODUÇÃO}

O direito constitucional comparado tem como ponto de partida e tema principal o surpreendente crescimento do constitucionalismo em todo o mundo ao longo dos últimos sessenta anos. ${ }^{3}$ Dentro da disciplina, a narração central desse crescimento focaliza dois períodos e conjuntos de avanços: a criação de leis domésticas para proteger direitos fundamentais e sua aplicação com a adoção do controle de constitucionalidade das leis em muitos países da Europa ocidental e no Japão após a Segunda Guerra Mundial e a criação de constituições e de tribunais constitucionais na Europa central e oriental, a partir de $1989 .{ }^{4}$ Contudo, apesar das importantes e fascinantes diferenças encontradas nas formas como esses avanços se deram (cujo estudo é um elemento central da disciplina), em sua trama fundamental são adotados os elementos essenciais do modelo de constitucionalismo norte-americano.

Esses elementos essenciais estipulam uma incompatibilidade necessária e fundamental entre a supremacia legislativa e a proteção efetiva dos direitos fundamentais, de modo que optar por esta última exige "constitucionalizar" esses direitos, nos seguintes sentidos específicos. Primeiro, conceder aos direitos fundamentais um status jurídico mais elevado do que o da legislação. Segundo, petrificá-los contra emendas ou revogações legislativas ordinárias. Terceiro, impor seu status jurídico mais elevado por meio de poder judicial que anule legislação conflitante, de modo que o exercício desse poder não seja passível de revisão por maioria legislativa simples. Parafraseando brevemente John Marshall, ou os direitos individuais são lei suprema, petrificados e aplicados por um judiciário, não passível de revisão, ou eles são lei ordinária modificável por maioria legislativa: "entre essas duas alternativas, não há meio-termo."5

A adoção desse modelo na Europa ocidental e em outros lugares após 1945 e, novamente, na Europa central e oriental após 1989, quase sempre envolveu passar de um lado da incompatibilidade para o outro: uma mudança histórica e deliberada da supremacia legislativa para a supremacia constitucional, por meio da petrificação de declarações de direitos como lei suprema e da concessão, a alguns grupos de juízes (ou autoridades quase-judiciais), do poder não passível de revisão para invalidar legislação incompatível. ${ }^{6}$ Em resumo, o recente crescimento do constitucionalismo mundial tem sido o crescimento do modelo de constitucionalismo inventado nos Estados Unidos.

Houve, contudo, nos últimos vinte anos entre um grupo diferente de países, um conjunto de avanços, coletivamente menos percebidos, que apresenta uma alternativa intrigante para esse modelo, uma alternativa que rejeita seu axioma central de que as reivindicações de supremacia legislativa e a tutela jurídica efetiva de direitos fundamentais são necessariamente incompatíveis e mutuamente excludentes, ou seja, um sistema legal pode endossar uma ou outra, mas não ambas. ${ }^{?}$

Entre 1982 e 1998, três países da Comunidade Britânica, o Canadá, a Nova Zelândia e o Reino Unido - países que estiveram anteriormente entre os últimos bastiões democráticos 
da supremacia legislativa tradicional - adotaram declarações de direitos e garantias que se afastavam de maneira autoconsciente do modelo norte-americano e buscavam reconciliar e equilibrar as reivindicações opostas para criar um meio termo entre elas, em vez de adotar uma transferência indiscriminada de um polo para o outro.

De modo mais notável, embora concedam aos tribunais o poder de proteger direitos, eles desvinculam o controle de constitucionalidade da supremacia judicial ao dar poderes aos parlamentos de terem a última palavra.

Claro, é a tensão percebida entre as duas reivindicações dentro de um sistema político democrático o que se considera, com frequência, ser responsável pela criação da dificuldade contramajoritária $^{8}$ e dos diversos descontentamentos correlatos associados ao tradicional judicial review. Desta maneira, esses países criaram um terceiro e novo modelo de constitucionalismo, que se posiciona entre os dois modelos polares: a supremacia constitucional e a supremacia legislativa.

Muito recentemente, como peça central do que vem sendo descrito como "uma notável nova era do constitucionalismo no Reino Unido", o Parlamento britânico promulgou a Lei dos Direitos Humanos de $1998^{10}$ (doravante, LDH). Ao incorporar a Convenção Europeia dos Direitos Humanos ao direito interno, ${ }^{11}$ essa lei criou, pela primeira vez na Grã-Bretanha, uma declaração de direitos abrangentes que, em conteúdo, é comparável tanto àquela dos Estados Unidos quanto às das histórias de sucesso da narração supracitada. Mas, a maneira pela qual tais direitos foram incorporados pela $\mathrm{LDH}$, como aconteceu antes dela com as declarações de direitos do Canadá e da Nova Zelândia, corresponde a uma rejeição deliberada ao modelo de constitucionalismo norte-americano e seus excessos de poder judicial. No lugar dos excessos de poder judicial, tem-se tentado criar, entre os tribunais e os parlamentos, equilíbrio institucional, responsabilidade conjunta e diálogo deliberativo quanto à proteção e aplicação dos direitos fundamentais que, acreditam esses países, são aquilo que as reivindicações fundamentais e legítimas da soberania parlamentar exigem.

O experimento realizado por esses três países da Comunidade Britânica para transcender a lei do meio termo excluído de Marshall e para reconciliar o que o paradigma dominante postula como valores incompatíveis é, obviamente, um experimento interessante e importante, pois, se bem-sucedido, criará um espaço analítico e prático no direito constitucional interno e no comparado que, em geral, pensava-se não existir.

Em vez de uma escolha mutuamente excludente entre dois polos incompatíveis, o modelo da Comunidade Britânica permite vislumbrar a inovadora possibilidade de um continuum que se alonga da supremacia legislativa absoluta até o modelo norte-americano de declaração de direitos e garantias plenamente constitucionalizada, com diversas posições intermediárias que realiza algo de cada. Ademais, embora todas as três declarações de direitos da Comunidade Britânica rejeitem o modelo norte-americano, no sentido de que buscam tornar a proteção de uma declaração de direitos consistente com suas concepções tradicionais de democracia e de soberania parlamentar, cada uma o faz de uma maneira diferente e, 
assim, ocupa uma posição diferente nesse continuum entre os dois polos.

Além de sua importância por fornecer novas opções institucionais, o novo modelo indica soluções para diversos problemas teóricos e práticos que há muito são vistos como corruptores do modelo norte-americano. Ao tentar criar responsabilidade conjunta e diálogo genuíno entre tribunais e parlamentos a respeito dos direitos fundamentais, o novo modelo promete tanto trazer importantes questões de princípio de volta ao debate legislativo e popular, quanto fornecer uma resolução radicalmente direta para as dificuldades democráticas associadas ao contrle de constitucionalidade tradicional. ${ }^{12}$

Este artigo identifica, analisa e avalia o novo modelo de constitucionalismo da Comunidade Britânica. $\mathrm{O}$ item 2 descreve brevemente as características essenciais do modelo dominante de constitucionalismo norte-americano e sua ampla adoção ao redor do mundo nos últimos sessenta anos. No item 3, explico como cada um dos três países da Comunidade Britânica rejeitou esse modelo promulgando suas recentes declarações de direitos e garantias, bem como a maneira diferente como cada um deles tentou reconciliar aquilo que o modelo dominante assume como irreconciliável. No item 4, avalio esse novo modelo de constitucionalismo: 4.1 explica com maiores detalhes sua natureza e características gerais; 4.2 compara os modelos da Comunidade Britânica com o dos Estados Unidos analisando (a) os benefícios e vantagens potenciais do primeiro, (b) em que medida são distintos e (c) o impacto do novo modelo sobre as justificativas existentes para o controle de constitucionalidade tradicional; 4.3 pondera qual das três versões do novo modelo - a canadense, a neozelandesa ou a britânica - está mais propensa a concretizar seus benefícios gerais.

\section{O MODELO NORTE-AMERICANO DE CONSTITUCIONALISMO E SUA AMPLA ADOÇÃO APÓS 1945}

A Constituição dos Estados Unidos da América foi, é claro, tanto produto de uma revolução bem-sucedida quanto uma revolução bem-sucedida por si própria - no constitucionalismo e no pensamento constitucional. ${ }^{13}$ Ela foi projetada, acima de tudo, em contraste direto à constituição britânica ${ }^{14}$ que, quaisquer que fossem os méritos gerais de suas alegações de proteger a liberdade adequadamente, era condenada pelos ex-súditos coloniais norte-americanos por ter deixado de proteger seus direitos e liberdades garantidos pelo direito consuetudinário. Rejeitando direta e conscientemente a fundamental teoria constitucional britânica da soberania do Parlamento, ${ }^{15}$ os novos Estados Unidos criaram um sistema de governo baseado na noção de que o poder legislativo é juridicamente limitado e, em seguida, concederam poder aos tribunais para aplicar esses limites. ${ }^{16}$ Em cada uma das três questões a seguir, a Constituição dos Estados Unidos deu uma resposta oposta àquela da constituição britânica e, ao fazê-lo, definiu as diferenças polares entre os modelos de supremacia legislativa e constitucional do constitucionalismo. Primeiro, a Constituição dos Estados Unidos, incluindo a Declaração de Direitos e Garantias e todas as emendas subsequentes, é o supremo 
direito nacional (the supreme law of the land), o que significa que ela prevalece em caso de conflito com qualquer outra norma jurídica, seja federal ou estadual, não importando se tal norma foi criada antes ou depois da Constituição. ${ }^{17}$ Em contraste, na Grã-Bretanha, as Leis do Parlamento são o supremo direito nacional, e seus conteúdos são juridicamente ilimitados. ${ }^{18}$ Segundo, a Constituição dos Estados Unidos é "petrificada" no sentido de que não pode ser emendada por lei ordinária do legislativo, mas somente por procedimento especial e distinto que exige maioria absoluta, detalhado no Artigo V. ${ }^{19}$

$\mathrm{Na}$ Grã-Bretanha, a soberania do Parlamento significa que ele pode emendar ou revogar qualquer legislação prévia por maioria simples. De fato, ele pode fazê-lo de maneira tanto explícita quanto tácita. De acordo com a teoria da revogação tácita, uma lei posterior em conflito com uma anterior revoga esta última naquilo em que conflitam. Essa teoria é um mecanismo central para assegurar que o Parlamento não pode vincular seus sucessores em forma ou substância, e que cada novo Parlamento goza da mesma soberania plena e igual de seus predecessores. ${ }^{20}$ Terceiro, a supremacia da Constituição dos Estados Unidos é aplicada pelo Judiciário, o qual tem o poder e o dever de anular qualquer norma jurídica, incluindo legislação federal, que conflite com ela, sendo que o parlamento federal e os legislativos estaduais são impotentes para agir por maioria simples contra as decisões do Judiciário. ${ }^{21}$ Mesmo com a maioria absoluta exigida de dois terços de ambas as casas, o Congresso pode apenas propor emendas constitucionais; são os legislativos estaduais (ou convenções) que devem ratificá-las.

$\mathrm{Na}$ Grã-Bretanha, a soberania do Parlamento significa que nenhum tribunal tem poder para questionar a validade de uma lei parlamentar, o supremo direito nacional. ${ }^{22}$

Antes de 1945, o modelo de supremacia legislativa, tal como exemplificado não apenas pela teoria britânica de soberania parlamentar, mas também pela doutrina francesa de que leis do parlamento são a expressão suprema da vontade geral do povo, ${ }^{23}$ era o modelo dominante de constitucionalismo em todo o mundo, particularmente no que diz respeito à questão dos direitos individuais e das liberdades civis. ${ }^{24}$ Os pouquíssimos tribunais que tinham poder para realizar o controle de constitucionalidade da legislação nacional quanto a violações de direitos fundamentais enquadravam-se em uma ou mais destas três categorias: eram experimentos recentes ou breves; suas reivindicações por tal poder eram veementemente contestadas; ou exerciam-no em teoria, mas não na prática. Assim, a Irlanda instituiu explicitamente o controle de constitucionalidade judicial em sua Constituição de $1937,{ }^{25}$ a qual incluía proteção a direitos fundamentais.

Os dois primeiros tribunais constitucionais especializados foram instituídos nas novas repúblicas da Áustria (1920-1933) e da Tchecoslováquia (1920-1938), mas a jurisdição da primeira era limitada, até 1929 , a petições dos outros poderes do governo e tratavam apenas de questões de separação dos poderes. ${ }^{26} \mathrm{Na}$ Espanha, um tribunal especializado, o Tribunal de Garantias Constitucionais, funcionou entre 1933 e 1936, durante a malfadada Segunda República. ${ }^{27} \mathrm{Na}$ Alemanha de Weimar, os dois tribunais gerais mais elevados, ocasionalmente, 
reivindicavam para si o controle de constitucionalidade, apesar do silêncio da Constituição quanto ao assunto, mas, na prática, raramente o exerciam, e nunca a respeito de direitos individuais. ${ }^{28}$

O fracasso óbvio e catastrófico do modelo de supremacia legislativa do constitucionalismo em evitar tomadas de poder totalitaristas, bem como a avalanche de violações de direitos humanos antes e durante a Segunda Guerra Mundial, resultaram na adoção dos elementos essenciais do polarmente oposto modelo norte-americano, quase sem exceção, sempre que surgia a oportunidade para um país ter um novo começo e promulgar uma nova constituição.

Para proteger e expressar de forma efetiva seu compromisso para com os direitos e liberdades humanas fundamentais, os países abandonaram, um após outro, a supremacia legislativa, mudando para uma declaração de direitos petrificada com status de lei suprema que fosse judicialmente (ou quase-judicialmente) aplicada. Isso incluiu as três potências do Eixo: Alemanha (1949), Itália (1948) e Japão (1947); a Espanha (1978), Portugal (1982) e Grécia (1975), após emergirem de ditaduras autoritárias; a França da atual Quinta República (1958), ${ }^{29}$ bem como Chipre (1960), Turquia (1961) e Bélgica (1984). A Áustria reinstituiu seu tribunal constitucional e sua constituição de 1929, com emendas, em 1945.

Atualmente, dentro da Europa ocidental, apenas Holanda e Luxemburgo não alteraram suas constituições para se afastar do modelo tradicional de supremacia legislativa, nem permitem qualquer forma controle de constitucionalidade em sua legislação. ${ }^{30}$ Até o ano de 2000, a Finlândia constituía o terceiro membro desse grupo exclusivo, mas, de acordo com sua nova Lei Básica, um poder muito limitado de controle de constitucionalidade passou a ser concedido aos tribunais. ${ }^{31}$ Isso a coloca mais ou menos em sintonia com os três outros países nórdicos, Suécia, Dinamarca e Noruega, que compartilham uma tradição na qual um poder de controle de constitucionalidade residual e final é reconhecido em teoria, mas, na prática, cede lugar à supremacia legislativa. ${ }^{32} \mathrm{~A}$ Suíça permite o controle de constitucionalidade da legislação estadual (cantonal), mas não a da legislação federal.

Uma segunda onda de constitucionalização teve lugar na Europa central e oriental, após a dissolução do sistema soviético em 1989. A criação de tribunais constitucionais que exercem o controle de constitucionalidade tem sido um fenômeno universal, juntamente com novas constituições e declarações petrificadas de direitos. Isso inclui Polônia (1986), ${ }^{33}$ Hungria (1990), Rússia (1991), Bulgária (1991), República Tcheca (1992), República Eslovaca (1992), Romênia (1992) e Eslovênia (1993) ${ }^{34}$ Além disso, pelo menos vinte novas constituições foram adotadas em países africanos desde 1989, muitas contendo declarações de direitos e controle de constitucionalidade, de modo mais proeminente, talvez, a África do Sul em 1996. ${ }^{35}$

Com certeza, tanto os conteúdos dos direitos fundamentais protegidos quanto as formas de controle de constitucionalidade adotadas na Europa ocidental após 1945 e, novamente, na Europa oriental e na África após 1989 diferem de modo interessante e importante da situação nos Estados Unidos. Em termos de conteúdo de direitos, embora sejam semelhantes 
de modo geral, há três diferenças principais. Primeira, enquanto a Constituição dos Estados Unidos é notoriamente uma "carta de direitos negativos" ${ }^{36}$, contendo apenas o rol daquilo que os governos estaduais e o federal estão proibidos de fazer a seus cidadãos, algumas das novas constituições também contém alguns direitos positivos, aquilo que os governos devem fazer por eles. ${ }^{37}$ Segunda diferença, enquanto nos Estados Unidos as disposições de direitos vinculam apenas o governo, e não os atores privados, com a única exceção da Décima Terceira Emenda, algumas poucas das novas constituições permitem a aplicação "horizontal" de determinadas disposições de direitos, de modo que podem efetivamente vincular cidadãos comuns. ${ }^{38}$ Terceira, direitos específicos óbvios estão presentes em algumas constituições enquanto estão ausentes na dos Estados Unidos e vice-versa, e, a respeito de direitos comuns, há diferenças nos níveis de proteção e na extensão em que alguns direitos podem ser limitados. ${ }^{39}$

Quanto às formas de controle de constitucionalidade, há também diversas diferenças importantes e bem conhecidas entre os Estados Unidos e a Europa em particular. Primeira e mais notoriamente, existe a prevalência do sistema "concentrado" do controle de constitucionalidade, muitas vezes conhecido como modelo "europeu" ou "austríaco" ${ }^{40}$, no qual, em geral, apenas um tribunal do sistema jurídico - quase sempre chamado de tribunal constitucional - recebe o poder aplicar o controle de constitucionalidade. Ademais, esse tribunal não é, em geral, aquele mais elevado que já existia, mas um novo tribunal cuja única função é a de exercer esse poder e cujos membros são nomeados de uma maneira diferente, mais manifestamente política, daquela como os juízes ordinários o são.

Esses tribunais ordinários não podem declarar uma lei inconstitucional, mas podem, e algumas vezes devem, remeter a questão ao tribunal constitucional. Isso se compara ao sistema "difuso" ou "descentralizado" dos Estados Unidos e de outros lugares, no qual cada tribunal, seja estadual ou federal, tem o poder do judicial review. ${ }^{41}$ Em segundo lugar está a questão de quem pode buscar o judicial review da legislação. A distinção padrão entre judicial review "abstrata" e "concreta" refere-se ao fato de a constitucionalidade da legislação poder ser questionada por cidadãos comuns no contexto de uma "ação ou litígio", ou apenas por determinados atores políticos específicos, que buscam o que é essencialmente um parecer consultivo vinculante (binding advisory opinion) no qual a validade da legislação é considerada em abstrato, fora do contexto de qualquer conjunto de fatos ou da aplicação específica. ${ }^{42}$ Nos Estados Unidos, é claro, apenas o judicial review concreto é possível, de acordo com Artigo III. Em outros lugares, a maioria dos sistemas permite tanto o judicial review abstrato quanto a concreto. ${ }^{43}$ Em terceiro vem a questão temporal do judicial review: a inconstitucionalidade da legislação pode ser contestada apenas antes de sua promulgação final ("revisão a priori), somente após sua entrada em vigor ("revisão a posteriori"), ou em ambos os casos? Nos Estados Unidos, com certeza, a resposta é: somente após e por tempo ilimitado; na França, apenas antes. A maioria dos outros países segue os Estados Unidos nessa questão, embora haja costumeiramente limites temporais para a busca do controle abstrato. ${ }^{44}$ Finalmente, existem diferenças significativas no estilo das decisões judiciais e nos métodos de raciocínio, 
a maioria das quais fazem paralelo com as diferentes orientações gerais da Common Law em comparação com as do Civil Law. Uma questão secundária interessante e importante diz respeito à permissibilidade de votos judiciais dissidentes. Embora haja uma tendência clara na direção de permiti-los, alguns países insistem na aparência de unanimidade, acreditando que votos dissidentes solapam a autoridade percebida do tribunal e a objetividade do direito constitucional. ${ }^{45}$

Apesar dessas diferenças importantes e interessantes, tanto no conteúdo dos direitos fundamentais quanto na forma do controle de constitucionalidade adotado por muitos países que abandonaram a supremacia legislativa para dar maior proteção aos direitos individuais - diferenças que são objetos de estudo centrais em cursos e textos de direito constitucional comparado -, elas constituem, em última instância, variações dentro do modelo norte-americano de constitucionalismo, não modelos diferentes, uma vez que compartilham suas características essenciais. Quais sejam: um conjunto específico de direitos e liberdades fundamentais com o status de lei suprema, petrificado contra emenda ou revogação por maiorias legislativas simples e aplicado por um tribunal independente (na França, esse órgão é chamado de "conselho"), que tem o poder de anular e invalidar a legislação que considere em conflito com esses direitos, estando os parlamentos juridicamente impotentes para atuar por meios políticos ordinários contra as decisões de tal tribunal. Esses elementos essenciais, mais uma vez, definem um arranjo constitucional que é, em todos os aspectos, oposto à situação na qual reina a supremacia legislativa.

De acordo com a supremacia legislativa, o parlamento não é de forma alguma juridicamente limitado; seus atos legislativos constituem a forma mais elevada de lei conhecida no sistema jurídico; não há qualquer lei que não possa ser emendada ou revogada por maioria simples e nenhuma outra instituição tem o poder de questionar a validade de quaisquer de seus atos legislativos. Os termos supremacia legislativa e supremacia judicial, assim, referem-se à qual instituição detém primariamente a tarefa de declarar e proteger os direitos e liberdades dos cidadãos.

\section{AS TRÊS DECLARAÇÕES DE DIREITOS E GARANTIAS DA COMUNI- DADE BRITÂNICA}

Assim como os outros países que acabamos de discutir, os três países em foco da Comunidade Britânica - Canadá, Nova Zelândia e Reino Unido - buscaram, nos últimos vinte anos, criar, para direitos fundamentais, maior tutela jurídica do que é possível dentro da supremacia legislativa tradicional. Porém, diferentemente dos outros, esses três países tentaram fazê-lo enquanto, deliberadamente, recusavam-se a abraçar o modelo norte-americano e, em particular, a palavra final que este concede ao judiciário quanto ao que é o direito nacional (the law of the land).

Consequentemente, eles criaram um novo terceiro modelo de constitucionalismo, lo- 
calizado intermediariamente entre a declaração de direitos plenamente constitucionalizada e a supremacia legislativa plena. O Canadá foi o pioneiro, enquanto os outros dois países, que com ele compartilham tradições jurídicas, políticas e culturais, observaram-no, aprenderam com ele e, por fim, adaptaram o exemplo canadense, utilizado por eles como ponto de partida.

\subsection{A CARTA DE DIREITOS E LIBERDADES CANADENSE DE 1982}

Antes de 1982, os parlamentos provinciais e o federal do Canadá exerciam coletivamente a mesma soberania parlamentar gozada pelo Parlamento mãe em Londres. Embora a alocação do poder legislativo fosse constitucionalmente dividida entre legislativos federais e provinciais, de acordo com a Lei da América do Norte Britânica (British North America Act) de 1867, a constituição que efetivamente existia no Canadá; todo poder legislativo se esgotava nessa alocação. Nenhum poder era "retido pelo povo" para além da autoridade de todos os parlamentos, de modo que o poder legislativo total era ilimitado e nenhum tribunal tinha poder de anular qualquer ato legislativo, exceto se a alocação ou o federalismo estivessem em jogo. Como descreve um comentador da situação: a única questão constitucional era "qual jurisdição (federal ou provincial) deveria ter o poder de julgar uma injustiça e não se a injustiça deveria ser completamente proibida." ${ }^{46}$

Em 1960, o parlamento federal promulgou a Declaração de Direitos e Garantias Canadense (doravante DDGC), uma lei que exige que:

Cada lei do Canadá, a menos que um Ato do Parlamento do Canadá declare expressamente que ela deva vigorar a despeito da Declaração de Direitos e Garantias Canadense, deve ser interpretada e aplicada de modo a não ab-rogar, reduzir ou infringir [...] quaisquer direitos e liberdades aqui reconhecidos e declarados. ${ }^{47}$

Esses direitos, detalhados na Seção 1, que declaram que eles "existem sem discriminação por razão de raça, nacionalidade, cor, religião ou sexo" incluem:

O direito [... à vida, à liberdade, à segurança da pessoa e ao gozo da propriedade, bem como o direito de deles não ser privado exceto por meio do devido processo legal; o direito[...] à igualdade perante a lei e à proteção da lei; à liberdade religiosa; à liberdade de expressão; à liberdade de reunião e associação e à liberdade de imprensa. ${ }^{48}$

Essa declaração de direitos, uma lei ordinária que vincula apenas o governo federal e não as províncias, foi a primeira de uma série de novos experimentos nos três países da Comunidade que buscaram reconciliar a soberania parlamentar com a proteção aos direitos fundamentais, formando o pano de fundo sobre o qual todas as versões posteriores foram pensadas e comparadas.

A DDGC não especifica o que os tribunais têm o poder ou a obrigação de fazer caso, na ausência de uma declaração parlamentar expressa, uma lei não puder ser interpretada de forma congruente com quaisquer dos direitos protegidos. Devem os tribunais aplicar a lei ou 
invalidá-la? Embora uma maioria simples da Suprema Corte do Canadá tenha concordado, dez anos depois de sua promulgação, ser a segunda alternativa a melhor, a ação na qual houve essa concordância foi a única ocasião em que se empregou a DDGC para derrubar uma lei incompatível. ${ }^{49}$ No geral, e apesar dessa única decisão, a DDGC é quase universalmente vista como ineficiente porque os tribunais tendem a interpretar seu impacto e seu poder através das lentes tradicionais da soberania parlamentar, limitando, assim, o âmbito de aplicação e a eficácia dos direitos protegidos. ${ }^{50}$ Dessa maneira muito juízes, concordando ou não que os tribunais estão autorizados a invalidar leis incompatíveis, enfraqueceram a DDGC ao adotar a assim chamada "teoria dos conceitos congelados" (frozen concepts theory), que a interpretava como mera codificação de direitos (em grande parte, consuetudinários) dos cidadãos que vigoravam em 1960, e não como criadora de direitos novos. ${ }^{51}$

Essa interpretação teve o efeito tanto de imunizar todas as leis anteriores a 1960, visto que expressavam e determinavam o conteúdo desses direitos, quanto o de reduzir o alcance do significado dos direitos quando avaliados em relação a leis posteriores. Além disso, os direitos textualmente ilimitados e expressos de modo abstrato foram algumas vezes considerados excessivamente gerais para afetar a interpretação de medidas parlamentares subsequentes ou para serem julgados em conflito com estas últimas. ${ }^{52}$ Dessa forma, considerou-se que a declaração de direitos, uma lei ordinária e não petrificada, menos reconciliou a soberania parlamentar com os direitos fundamentais do que permitiu que tal soberania aceitasse tais direitos precisamente da maneira como o modelo padrão de exclusividade mútua teria previsto. $\mathrm{O}$ fracasso que se percebeu na DDGC parecia apenas confirmar a escolha óbvia: ou soberania parlamentar ou proteção de direitos fundamentais, mas não ambas: não há meio termo possível. Mas nem o Canadá nem os outros dois países da Comunidade Britânica haviam finalizado o experimento da reconciliação. ${ }^{53}$

O próximo grande avanço foi a promulgação da Carta Canadense de Direitos e Liberdades, formando a Parte 1 da Lei da Constituição de 1982. A Seção 1 da Carta "garante os direitos e liberdade nela especificados, sujeitos apenas aos limites razoáveis prescritos pela lei como se pode justificar e comprovar em uma sociedade livre e democrática". Nas Seções 2 e 6 a 15, a Carta arrola os direitos substantivos e as liberdades fundamentais que devem ser garantidos a "todos". Aqueles incluem "as liberdades fundamentais" de mobilidade, religião, pensamento, credo, opinião e expressão; o direito à vida, à liberdade e à segurança da pessoa e a igualdade de direitos. ${ }^{54}$

A Carta foi uma parte essencial da "repatriação" da Constituição do Canadá, desvinculando-a do Reino Unido, negociada pelo Primeiro Ministro Pierre Trudeau e tecnicamente concretizada pela Seção 2 da Lei do Canadá de 1982 promulgada pelo Parlamento britânico. ${ }^{55}$ Como é notório, Trudeau almejava um status plenamente constitucionalizado para a Carta de acordo com modelo norte-americano, mas diversos primeiros ministros provinciais objetaram em princípio ao consequente abandono da tradicional teoria da soberania parlamentar, bem como à sujeição provincial a direitos nacionalizados. ${ }^{56} \mathrm{~A}$ principal solução 
conciliatória, alcançada na última hora, foi a inserção na Carta da cláusula "não obstante" da Seção 33, emprestada da Seção 2 da Declaração de Direitos de 1960, mas transformada no novo contexto. Essa cláusula capacitava os parlamentos provinciais e o federal a anular, por maioria simples, os direitos contidos na Carta por um período renovável de 5 anos. ${ }^{57}$

Assim, a Seção 33 foi especificamente projetada como uma solução conciliatória entre a tradicional soberania parlamentar e o modelo do constitucionalismo norte-americano, mas uma solução conciliatória de um tipo diferente daquele contido na Declaração de Direitos de $1960 .{ }^{58}$ Nesta última, a disposição funcionava como uma limitação sobre a capacidade do Parlamento para anular os direitos protegidos no contexto tradicional da soberania parlamentar, enquanto, no novo contexto de uma Carta constitucional vista como lei superior, a anulação funciona como um poder especial ou como uma saída para a ação parlamentar. ${ }^{59}$ A questão, claro, era: seria a Carta mais bem-sucedida do que a Declaração de Direitos na reconciliação dos dois valores?

Como ponto inicial, vamos examinar o modo pelo qual a Carta adere aos elementos essenciais do modelo norte-americano discutido acima e aquelas pelas quais se afasta deste. Primeiro, quanto ao status jurídico da Carta, a Seção 52 da Lei da Constituição declara que "a Constituição do Canadá”, definida para incluir a Lei da América do Norte Britânica, de 1867, e emendas juntamente com o a própria Lei da Constituição (Carta sendo sua Parte 1), é a lei suprema do Canadá e que "qualquer lei que apresente incongruências com as disposições da Constituição não tem, quanto a tais incongruências, qualquer efeito”. De acordo com a Seção 32, a Carta (diferentemente da DDGC) aplica-se aos legislativos e aos governos tanto do Canadá quanto das províncias.

Segundo, a Carta é petrificada no sentido de que a Constituição da qual faz parte somente pode ser emendada de acordo com as disposições contidas nas Seções 38 a 49 da Lei da Constituição, cuja forma geral exige o consenso de ambas as casas do Parlamento e ao menos dois terços das províncias contendo no mínimo cinquenta por cento da população de todas as províncias. ${ }^{60}$

Terceiro, embora não haja qualquer disposição explícita concedendo aos tribunais o poder de derrubar leis incongruentes com a Carta, essa parece ser a intenção clara da Seção 52 da Lei e das Seções de 1 a 24 da Carta (a cláusula da aplicação) consideradas em conjunto $^{61}$ e a Suprema Corte do Canadá tem agido desta maneira desde 1982. ${ }^{62}$ Como colocado acima, com exceção da única ocasião de divisão profunda conforme a DDGC, esse foi um novo começo para os tribunais canadenses - e, de fato, para os países de língua inglesa da Comunidade Britânica como um todo - visto que esses tribunais, anteriormente, haviam tido poder apenas em relação à tarefa de policiar a alocação federal-provincial dos poderes legislativos.

Até este ponto, a Lei da Constituição e a Carta adotam todas as características essenciais do modelo norte-americano: (1) direitos fundamentais com status de lei suprema; (2) petrificados contra emenda ou revogação por maiorias legislativas simples e (3) aplicadas 
por tribunais detentores do poder do judicial review. A solução conciliatória obtida por aqueles que eram contra o completo abandono da supremacia parlamentar e que foi projetada para evitar a adoção plena desse modelo é a disposição contida na Seção 33 da Carta. Essa disposição rejeita exatamente a característica final do modelo padrão, qual seja, a de que o exercício pelo tribunal de seu poder para derrubar legislação conflitante com um direito fundamental é final e não pode ser revertido pelo legislativo, pois isto é precisamente o que a Seção 33 permite que os legislativos façam. ${ }^{63}$

A Seção 33 (1) declara o seguinte:

O parlamento ou o legislativo de uma província pode expressamente declarar em uma lei do parlamento ou do legislativo, conforme o caso, que uma lei ou uma sua disposição deve vigorar não obstante uma disposição incluída na Seção 2 ou nas Seções de 7 a 15 (as disposições de direitos substantivos) desta Carta.

De acordo com a Seção 33 (3) e (4), essa anulação legislativa de um direito da Carta vigora por um período máximo de cinco anos e pode ser promulgada de novo. ${ }^{64}$

De acordo com a intenção daqueles que insistiam em sua inclusão como o preço a ser pago por se consentir a constitucionalização dos direitos da Carta, a disposição anulatória (override provision) preservaria ao menos aquele elemento essencial e básico da soberania parlamentar que garante aos legislativos (mais do que aos tribunais) o poder máximo para determinar se uma promulgação é ou não direito nacional. Desta maneira, a Seção 33 limitaria formalmente o poder judiciário. Como previsto de forma mais positiva por alguns, a Seção 33 forneceria a base institucional para uma nova concepção de tutela de direitos no contexto do sistema político democrático, uma alternativa contextualmente atrativa para a supremacia judicial no estilo dos Estados Unidos. ${ }^{65}$

Enquanto constitucionalmente se presume que os direitos da Carta prevaleçam quando entrem em conflito com uma promulgação legislativa, tal pressuposição pode ser expressamente refutada por um parlamento atuando com maioria simples, o que cria um papel tanto para os tribunais quanto para os deputados eleitos no equilíbrio entre direitos e outras reivindicações da sociedade. Passando das implicações jurídicas da Seção 33 para as políticas, era de se esperar que a utilização da Seção 33 por um parlamento tivesse consequências políticas para além daquelas de rotina, forçando discussão e justificativa pautadas em princípio quanto aos méritos, antes que eleitores atentos aceitassem limitações a seus direitos. ${ }^{66}$ Desta maneira, um diálogo proveitoso entre os tribunais e os legislativos substituiria o monólogo judicial do modelo norte-americano. Freios e contrapesos seriam importados para a própria função de proteção a direitos.

Como é notório, as coisas não funcionaram da maneira que se esperava. ${ }^{67}$ Dois meses após a promulgação da Lei da Constituição, e em resposta à sanção da Lei sem seu consentimento, ${ }^{68}$ a Assembleia Nacional do Québec aprovou o Projeto de Lei 62, um uso geral e preventivo da Seção 33 para se autoimunizar, tanto quanto possível, contra a Carta constitucionalizada.$^{69}$ Essa lei, sozinha, adotou quatro providências. ${ }^{70}$ Primeira, ela revogou e promulgou novamente toda a legislação pré-Carta da província e ainda adicionou uma 
cláusula anulatória a cada uma (a característica "omnibus"). Segunda, a cláusula anulatória adicionada a cada uma tinha uma forma "padrão", simplesmente repetindo os dizeres da Seção 33, no sentido de rezar que "esta Lei vigorará não obstante as disposições das Seção 2 e 7 a 15 da Lei da Constituição de 1982”. Terceira, ela adicionou automaticamente tal cláusula anulatória padrão a toda legislação nova. Quarta, ela concedeu às cláusulas anulatórias um efeito retroativo para cobrir o período de dois meses contados da entrada em vigor da Carta. ${ }^{71}$

Na primeira ação em que interpretou a Seção 33 em 1988, Ford v. Québec, a Suprema Corte do Canadá manteve esse emprego controverso a despeito de alegações de que suas características omnibus e padrão violavam tanto a letra de uma exigência de especificidade quanto o espírito do empreendimento. ${ }^{72}$ A Corte fez isso interpretando que a Seção 33 continha apenas os requisitos formais mínimos, satisfeitos nessa ação e, portanto, proporcionava apenas um espaço limitado para o controle de constitucionalidade de exercícios de acordo com ela. ${ }^{73}$ Ela invalidou apenas a aplicação retroativa da anulação, aplicando ao texto da Seção 33 a presunção tradicional da interpretação jurídica a favor de efeitos prospectivos apenas. A permissibilidade de um emprego preventivo da anulação, como distinto de um emprego que responda a uma declaração de inconstitucionalidade pelo tribunal, não entrou em questão em Ford e parece ter sido presumida, embora obviamente a decisão no caso desfaça qualquer dúvida sobre o assunto. ${ }^{74}$

É interessante que, embora se tenha afirmado que a decisão da Corte de conceder à Seção 33 uma interpretação mais formal e mais facilmente satisfeita do que discutivelmente o texto sugere ou seus redatores intencionavam foi incitada (como sua interpretação da DDGC) por uma orientação tradicional para a soberania parlamentar, ${ }^{75}$ o verdadeiro resultado do episódio foi bem o oposto. Longe de deflagrar um movimento retrógrado de volta ao ponto de partida da soberania parlamentar tradicional, como foi em geral o que aconteceu com a DDGC após 1960, uma convenção constitucional parece ter manifestado, ao menos a respeito das outras províncias do Canadá e do Parlamento federal, que a disposição anulatória não deveria ser usada de forma alguma. ${ }^{76} \mathrm{Na}$ verdade, ela fora usada apenas uma vez por outra província além da de Québec, e isso aconteceu pouco antes da própria decisão do caso Ford. Tal se deu na província de Saskatchewan quando esta empregou a Seção 33 para encerrar uma greve dos seus servidores públicos e para anular a decisão do Tribunal de Recursos da província de que a Carta continha um direito implícito à greve, decisão que foi revertida pela Suprema Corte do Canadá, em $1987 .{ }^{77}$

Desta maneira, qualquer que fosse seu potencial teórico para oferecer um equilíbrio entre a soberania parlamentar e o controle de constitucionalidade, apresentando com isso uma nova estrutura de tutela de direitos, a Seção 33 não foi mais efetiva na prática do que a DDGC quanto a reconciliar as duas posições, ${ }^{78}$ embora seja interessante notar (com exceção do Québec) que ela foi ineficaz exatamente na direção oposta. Enquanto a DDGC não reduziu a dificuldade majoritária colocada pela soberania parlamentar ilimitada, a convenção contra seu uso impediu que a Seção 33 mitigasse a dificuldade contramajoritária colocada 
por um poder ilimitado do controle de constitucionalidade. Em ambos os casos, o resultado foi um rápido retrocesso para os dois pólos, se bem que polos opostos.

No geral, então, parece justo dizer que a experiência do Canadá provavelmente contribuiu pouco para enfraquecer a alegação de Marshall de que não existe meio termo. As experiências institucionais para experimentar e criar um meio termo, contudo, não terminaram por aí. Quando declarações de direitos e garantias posteriores foram apreciadas e promulgadas na Nova Zelândia e no Reino Unido, os participantes do debate estavam mais do que cientes dos supracitados eventos no Canadá, o qual, como país coparticipante da Comunidade Britânica, com cultura jurídica e tradição de soberania parlamentar semelhantes, foi visto como um exemplo muito mais relevante do que os Estados Unidos ou a Europa ocidental. Poderemos agora verificar se qualquer um deles foi capaz de chegar a uma reconciliação mais bem sucedida.

\subsection{A LEI DE DECLARAÇÃO DE DIREITOS DA NOVA ZELÂNDIA DE 1990}

Assim como a Carta canadense, a Lei de Declaração de Direitos e Garantias da Nova Zelândia de 1990 (doravante LDDNZ) começou como uma proposta do governo para constitucionalizar de forma plena um conjunto de direitos fundamentais no modelo padrão que enfrentou oposição política esmagadora em defesa da concepção tradicional no país de democracia e soberania parlamentar, e foi, desta maneira, emendada em uma tentativa de reconciliar as duas. Embora as disposições substantivas da LDDNZ tenham sido modeladas com base na Carta canadense e sejam bem semelhantes a estas, a maneira como a LDDNZ tenta reconciliar as duas posições, contudo, é bastante diferente.

governo trabalhista de Geoffrey Palmer publicou um Livro Branco em 1985 que propunha a promulgação de uma declaração de direitos como lei suprema plenamente constitucionalizada. O Livro Branco foi recebido com oposição generalizada nos círculos jurídicos e políticos sob alegação de que aquilo era desnecessário e de que se afastava muito das tradições jurídicas e políticas do país, as quais tinham forma muito semelhante às da soberania parlamentar britânica. Em consequência, o governo foi forçado a recuar e, por fim, reintroduziu uma versão emendada da declaração de direitos que foi promulgada em meio a amargas divisões partidárias. ${ }^{79}$

Assim como a Declaração de Direitos e Garantias Canadense de 1960, a LDDNZ é uma lei ordinária - e não uma lei suprema - de declaração de direitos que não é petrificada, podendo ser emendada ou revogada como qualquer outra lei. Além disso, em nenhuma circunstância os direitos contidos na LDDNZ podem anular uma lei conflitante. A Seção 4 proíbe expressamente que os tribunais invalidem qualquer lei por incongruências com os direitos contidos na Seção 1 e, de maneira específica, elimina a regra que, do contrário, seria normal, de que leis anteriores e conflitantes são tacitamente revogadas pelos direitos contidos na Declaração de Direitos subsequente. ${ }^{80}$ Neste sentido, sua força jurídica é menor do que aquela de uma lei ordinária, em vez de ser maior, como acontece com a Carta canadense. 
Por outro lado, o método básico para aplicar os direitos nela contidos confere à LDDNZ um status bastante especial vis-à-vis leis ordinárias. Esse método consiste em impor um dever aos tribunais de interpretar todas as outras leis de modo consistente com os direitos contidos na LDDNZ, sempre que possível. Nas palavras da Seção 6, "sempre que uma promulgação puder ser interpretada de modo consistente com os direitos e liberdades contidos nesta Declaração de Direitos e Garantias, tal interpretação deve ser privilegiada em relação a qualquer outro sentido."

Assim, embora seu status jurídico seja o de uma lei ordinária, a LDDNZ é uma lei estrutural que determina como outras leis ordinárias devem ser interpretadas. Além disso, ela o faz legislando, não um conjunto de ferramentas interpretativas "neutras" - tais como determinar se os tribunais podem ou não levar o histórico legislativo em consideração ou se os cânones ejusdem generis e expressio unius est exclusio alterius devem ser presumidos -, mas legislando um conjunto de direitos substantivos.

Desta maneira, a LDDNZ pode ser entendida como uma declaração de direitos interpretativa, mais do que anulatória, como o é a Carta canadense: se e somente se uma lei não puder ser interpretada de forma consistente com a declaração de direitos, irá esta sobrepujar aquela. Esses dois tipos de declaração de direitos representam dois métodos diferentes para proteger direitos que podem tanto ser compatíveis com a preservação de elementos chave da soberania parlamentar quanto podem conceder aos parlamentos um papel institucional na proteção de direitos. De acordo com uma declaração de direitos anulatória, tal obrigação interpretativa é menos urgente porque a força jurídica protetória jaz no poder que tem o tribunal de anular leis conflitantes, mais do que em seu poder interpretativo de forçar um parlamento a pagar os custos políticos de violação clara e explícita de direitos. Em consequência, por exemplo, a Carta canadense não impõe tal dever interpretativo aos tribunais.

Como acabamos de ver, a LDDNZ protege os direitos nela contidos por intermédio do dever interpretativo que impõe aos tribunais de acordo com a Seção 6 e do consequente custo político conferido aos parlamentos de promulgar uma medida que muito claramente viole um direito tutelado com o qual não possa ser interpretada de maneira congruente ${ }^{81} \mathrm{Em}$ sua Seção 4, ela protege a soberania parlamentar ao declarar que tal legislação incongruente não pode ser invalidada pelos tribunais e que prevalece sobre a LDDNZ independentemente de quando foi promulgada.

Embora, por essa razão, juridicamente, a LDDNZ proteja uma versão particularmente forte da soberania parlamentar - no sentido de que não pode haver qualquer questionamento da validade de uma lei do Parlamento - ela de fato transfere poderes importantes para os tribunais de modo a proteger direitos fundamentais, quais sejam: o poder de controlar o significado das leis de uma maneira não encontrada nos cânones de interpretação jurídica. Ademais, essas duas disposições da LDDNZ, as Seções 4 e 6, conduzem claramente em direções opostas. ${ }^{82}$

A esse respeito, a experiência do Canadá com sua Declaração de Direitos e Garantias, de 
1960, é altamente relevante. A LDDNZ tem, em essência, o mesmo status jurídico e emprega o mesmo mecanismo protetório da DDGC e, contudo, como discutido acima, a impressão geral foi a de que os juízes canadenses tornaram a DDGC tão ineficaz que uma medida mais forte, a Carta, fez-se necessária. ${ }^{83} \mathrm{Na}$ verdade, com relação a três aspectos, a DDGC, textualmente falando, tutela mais os direitos fundamentais e menos a soberania parlamentar do que a LDDNZ. Primeiro, a DDGC não contém uma disposição como a da Seção 4 da LDDNZ, que nega expressamente aos tribunais o controle de constitucionalidade, mas silenciou quanto à questão de como deveriam ser aplicados os direitos. Como discutido acima, uma maioria simples da Suprema Corte do Canadá interpretou por fim esse silêncio como concedendo a ela o poder de invalidar leis incongruentes, embora este tenha sido exercido apenas uma vez e, mesmo assim, no contexto menos controvertido de uma lei anterior à declaração de direitos. ${ }^{84}$ Segundo, a cláusula "não obstante" da Seção 2 da DDGC reza que apenas por meio de declaração expressa pode o Parlamento anular os direitos nela contidos, de modo que, na ausência de tal declaração, parecia haver razão suficiente para acreditar que uma lei conflitante subsequente não prevaleceria sobre a DDGC, diferentemente do que acontece com a LDDNZ. ${ }^{85}$ Terceiro, de acordo com a DDGC, a obrigação de interpretar a legislação em consonância com os direitos fundamentais foi formulada em termos absolutos e não foi qualificada por uma cláusula "na medida do possível" como aconteceu na LDDNZ. Se tomado literalmente, isso implicaria que uma lei nunca poderia entrar em conflito com um direito. ${ }^{86}$

Como vimos, apesar desses suportes textuais, considerou-se que os tribunais canadenses foram ineficazes quanto à tutela de direitos. Em contraste, e ao contrário de muitas expectativas - e de algumas esperanças - de que a mudança de uma lei constitucional de declaração de direitos para uma ordinária iria efetivamente matá-la, a LDDNZ recebeu uma resposta judicial bastante diferente daquela recebida pela DDGC. ${ }^{87}$ Embora existam alguns problemas espinhosos de metodologia e de aplicação provenientes do caráter fragmentado do seu projeto (o assim chamado "quebra-cabeças das Seções 4-5-6"), ${ }^{88}$ o que levou algumas pessoas a concluírem que a LDDNZ não funcionou bem na prática, ${ }^{89}$ parece haver substantivamente tanto consenso sobre serem os tribunais da Nova Zelândia protetores entusiasmados dos direitos fundamentais quanto o há sobre não o serem os tribunais canadenses atuando conforme a DDGC.

Desde o princípio, a mais elevada corte da Nova Zelândia, o Tribunal de Recursos, insistiu em (a) que a LDDNZ deve ser interpretada de maneira ampla e tendo um propósito, em vez de o ser de maneira estreita e técnica, e (b) que o status de lei ordinária dos direitos não afetou sua importância ou significado. ${ }^{90}$ Com base nessa abordagem "centrada em direitos" 91 da LDDNZ, o Tribunal de Recursos rapidamente empregou os novos direitos no contexto da ação oficial do procedimento criminal instituindo uma regra de exclusão prima facie de provas obtidas com violação do direito ao aconselhamento jurídico e da garantia contra buscas e apreensões arbitrárias ${ }^{92}$ e, também, instituindo a possibilidade jurídica para a ação de indenização por violação da LDDNZ. ${ }^{93}$ 
Em termos de seu dever interpretativo, o Tribunal de Recursos adotou, em geral, um ponto de vista liberal, porém não radical, com relação à sua habilidade de interpretar as leis de modo congruente com a Declaração de Direitos, aceitando que assim faria sempre que a lei pudesse ser interpretada de maneira razoável, mas não quando fosse resultar em uma interpretação forçada. ${ }^{94}$

De modo geral, os tribunais têm-se mantido fortes na proteção dos direitos e desempenhado um papel importante no crescimento da cultura de direitos que muitos comentadores descreveram como estável e permanente. ${ }^{95}$ A razão pela qual as experiências da Nova Zelândia e do Canadá, com leis ordinárias de declaração de direitos juridicamente semelhantes, diferiram tanto não está completamente clara, embora o período de trinta anos entre suas promulgações tenha sido um período no qual tanto a prática quanto a legitimidade da articulação judicial e da aplicação de direitos em geral cresceram substancialmente, nos países da Comunidade Britânica, especialmente no contexto do direito administrativo. $O$ fracasso da DDGC também era bem conhecido na Nova Zelândia, de modo que os tribunais podem ter desejado conscientemente evitar a repetição do mesmo erro.

Por fim, uma característica procedimental importante da LDDNZ é que, de acordo com a Seção 7, o Procurador Geral deve examinar minunciosamente todos os projetos apresentados à Câmara dos Deputados e chamar a atenção de seus membros para quaisquer disposições que pareçam incompatíveis com os direitos e liberdades da LDDNZ. ${ }^{96}$ Novamente, isso é semelhante a uma disposição presente na DDGC que não consta da Carta canadense,$^{97} \mathrm{o}$ que reflete as diferentes estratégias das declarações de direitos interpretativas e das anulatórias. Embora aquela não negue a um parlamento o poder de agir de forma incompatível com direitos fundamentais, ela busca impelir o legislativo a adotar debates autoconscientes, bem divulgados, informados e baseados em princípios quanto a direitos, exigindo declarações claras de decisão legislativa para violá-los..$^{98} \mathrm{~A}$ ideia geral é a de que é apropriado para o parlamento ter a última palavra sobre o que é o direito nacional, mas apenas quando houver mecanismos para assegurar que, em seus procedimentos de tomada de decisão, os direitos sejam levados a sério.

\subsection{A LEI DE DIREITOS HUMANOS DO REINO UNIDO DE 1998}

A Lei de Direitos Humanos de 1998, que entrou em vigor em 2 de outubro de 2000, foi a peça central para a concretização das promessas eleitorais feitas pelo então governo trabalhista quanto à reforma constitucional ${ }^{99} \mathrm{e}$ foi descrita como "um momento decisivo na história constitucional e legal do Reino Unido." 100 Sua promulgação é também o ponto mais alto de um debate que se estendeu por décadas no Reino Unido sobre os méritos e a possibilidade jurídica de alguma forma de declaração de direitos codificada em geral, e a incorporação da Convenção Europeia dos Direitos Humanos (doravante CEDH) ao direito interno em particular. ${ }^{101} \mathrm{O}$ debate constitucional em torno dessas propostas teve lugar no contexto do seguinte dilema tradicional: por um lado, uma declaração de direitos na forma 
de lei ordinária estaria propensa a garantir proteção jurídica insuficiente a esses direitos, por outro, proteção maior que essa era algo problemático, se não impossível, de acordo com a constituição britânica e sua teoria central da soberania parlamentar. ${ }^{102}$

A novidade da solução encontrada pelo governo para esse dilema encontra-se na maneira como a CEDH foi incorporada, a qual, alega o governo, protege em essência "direitos da Convenção" 103 até o limite máximo dentro dos parâmetros da soberania parlamentar tal como entendida tradicionalmente. Não há dúvidas de que, no contexto legal e constitucional britânico, a mera existência de um conjunto de direitos codificados constitui uma mudança radical na cultura jurídica e política, independentemente da forma exata e do status jurídico que possui. Isso porque ele substitui a concepção existente de liberdades civis como essencialmente residuais - os cidadãos estão livres para fazer o que quer que a lei, o direito consuetudinário e a legislação delegada ${ }^{104}$ não os proíbam de fazer - por um conjunto de direitos primários ou afirmativos que limitam o que os cidadãos podem ser proibidos de fazer em primeiro lugar. A LDH, assim, promete alçar o discurso sobre direitos ao primeiro plano de uma cultura jurídica da qual estiveram antes amplamente ausentes. Todavia, da perspectiva do constitucionalismo comparado, o maior interesse está na forma e no status jurídico desses direitos, juntamente com os mecanismos para protegê-los, uma vez que, mesmo aceitando-se sem questionamentos a caracterização dada pelo governo à incorporação, eles acrescentam algo novo às opções existentes. Eles permitem ver uma terceira variação do tema da constitucionalização parcial, mas não plena, dos direitos fundamentais.

As disposições essenciais da LDH com relação à legislação "primária" (isto é, parlamentar) são as seguintes. A Seção 1 define os direitos e liberdades contidos na CEDH e seus protocolos, com exceção dos artigos 1 e 13 (que estão excluídos), como "os direitos da Convenção". De acordo com a Seção 3, todos os tribunais devem interpretar e colocar em vigor a legislação primária (bem como a secundária) de uma maneira que seja compatível com os direitos da Convenção, "na medida em que seja possível fazê-lo". De acordo com a Seção 4, caso um dos tribunais mais elevados especificados esteja convencido de que não é possível fazê-lo e de que a legislação primária em questão é, portanto, incompatível com um direito da Convenção, tal tribunal pode emitir uma declaração formal dessa incompatibilidade.

Contudo, de acordo com a Seção 4(6), não obstante uma declaração dessas, nenhum tribunal tem o poder de rejeitar ou invalidar tal legislação, a qual continua a ter pleno vigor e validade. Uma vez emitida uma declaração, a LDH não cria qualquer obrigação jurídica para o Parlamento nem para o governo de responder de qualquer forma que seja, mas ela concede poderes ao ministro pertinente para criar uma "ordem de reparação" de acordo com a Seção 10 e o Anexo 2. Esse procedimento de "rastreamento rápido" permite que um ministro emende legislação incompatível através de ordem submetida à consideração de ambas as Casas do Parlamento e por elas aprovada. ${ }^{105} \mathrm{~A}$ LDH obviamente não precisava dar poderes ao Parlamento para emendar ou revogar tal legislação visto que esse poder cla- 
ramente já existe. $\mathrm{O}$ governo manifestou diversas vezes sua crença de que o curso de ação normal seria o de que tal declaração "muito certamente incitaria o governo e o Parlamento a alterar a lei." ${ }^{106}$ De acordo com a Seção 19, sempre que um novo projeto de lei estiver sendo examinado no Parlamento, o ministro pertinente deve apresentar uma declaração por escrito antes de sua segunda leitura, tanto para afirmar que, de acordo com seu ponto de vista, o projeto é compatível com os direitos da Convenção, quanto para atestar que, embora tenha sido incapaz de fazer tal declaração, o governo deseja, ainda assim, prosseguir com ao projeto. Finalmente, a Seção 6 torna ilegal que uma "autoridade pública", definida de modo a excluir o Parlamento e incluir os tribunais, atue de maneira que seja incompatível com um direito da Convenção.

Para que se possa decidir se, e como, a LDH reconcilia de algum modo significativo a soberania parlamentar com a tutela aos direitos fundamentais, faz-se necessário levar em consideração tanto (a) o status jurídico alegado e o real dos direitos da Convenção quanto (b) os aspectos políticos, além dos jurídicos, da LDH. A respeito das três questões jurídicas centrais, o governo alega que deu "mais vigor"107 aos direitos da Convenção sem (I) dar a eles status de lei suprema, (II) petrificá-los contra emenda ou revogação e (III) conceder aos tribunais o poder do judicial review. Esta é a razão pela qual o governo reivindica ter incorporado os direitos sem se afastar do tradicional entendimento da soberania parlamentar. Consideremos agora de maneira cuidadosa cada uma dessas três questões. ${ }^{108}$

Em termos de status jurídico, os direitos da Convenção claramente não são lei suprema, com força normativa mais elevada do que uma lei legislada, visto que, de acordo com a Seção 4(6), uma lei declarada pelos tribunais incompatível com um direito da Convenção continua a ter plenos efeitos jurídicos. De fato, assim como acontece com a LDDNZ, os direitos da Convenção não têm o objetivo de possuir sequer a plena força jurídica de uma lei ordinária, pois a aplicação textual da Seção 4(6) a leis anteriores à LDH (e não apenas a leis posteriores a ela) significa a exclusão da teoria padrão da revogação tácita de uma lei incompatível mais antiga por uma mais recente. ${ }^{109}$ É por esta razão que tanto o governo quanto seus críticos concordam que, tecnicamente, os direitos da Convenção não foram de modo algum "incorporados" como parte do direito interno ordinário, mas devem produzir efeitos de alguma outra maneira. Esse ponto deixa claro, de maneira fortuita, que os direitos da Convenção poderiam ter recebido maior tutela dentro dos limites da teoria tradicional da soberania parlamentar.

Por outro lado, há características e implicações da LDH que dão aos direitos da Convenção maior proteção jurídica do que aos direitos contidos em leis ordinárias. Em primeiro lugar, é claro, está o dever interpretativo imposto a todos os tribunais de interpretar as leis de modo congruente com os direitos da Convenção sempre que possível. Isso contraria o método normal de interpretação jurídica, de acordo com o qual o exame do sentido claro do texto, mais do que o do propósito legal, é ainda primário ${ }^{110}$ e reduzirá substancialmente as ocasiões em que se encontrará um conflito que resulte em leis que sobrepujem direitos da Convenção. 
Segundo, nas raras ocasiões em que um conflito não puder ser evitado, a expectativa política, se não o dever jurídico, é a de que os direitos da Convenção irão, no final das contas, preponderar. Isso resulta não apenas do poder judicial concedido pela LDH de declarar incompatibilidade, mas também do próprio e importante fato de que a LDH pretende excluir a regra normal pela qual um direito da Convenção seria tacitamente revogado por uma lei subsequente incompatível, ${ }^{111}$ de modo que ele continue a ter toda força legal que os direitos da Convenção possuem. Essa é uma implicação clara do texto legal que não limita declarações de incompatibilidade a leis anteriores, pois, se as leis conflitantes subsequentes revogassem de maneira tácita os direitos da Convenção, não haveria, é claro, qualquer fundamento para uma declaração de incompatibilidade.

Este é o lado negativo de não terem sido incorporados como direito interno ordinário. Essa implicação foi também afirmada de maneira expressa pelo Lorde Juiz Presidente em um debate. ${ }^{112}$ Resta ver se os tribunais irão ou não pôr em vigor a intenção do governo com respeito a isso, pois existe um precedente de longa data que, como parte da teoria da soberania parlamentar, falta ao Parlamento o poder de imunizar suas leis contra a revogação tácita subsequente. ${ }^{113}$ Desta maneira, esse importante aspecto da LDH é incompatível com a concepção tradicional de soberania parlamentar. Logo, como resultado da combinação entre a exclusão da revogação tácita e a autorização para se declarar incompatibilidade, espera-se que os direitos da Convenção sejam política, embora não juridicamente, lei suprema.

Em terceiro lugar, diferentemente dos legislativos canadenses, de acordo com a Seção 33, o Parlamento não pode anular um direito da Convenção em uma ação específica, isto é, sem emendar ou revogar de maneira geral e expressa esse direito da Convenção. Se o Parlamento tentasse dizer que uma lei subsequente deve ser aplicada não obstante haja conflito com um direito da Convenção, uma declaração desse tipo pareceria não ter efeito jurídico adicional, pois nada na LDH impede que um tribunal declare tal incompatibilidade nessas circunstâncias. É claro que, em resposta, o Parlamento pode não emendar a lei incompatível sob o fundamento de que o tempo todo deixou clara sua intenção, mas a questão é que o Parlamento não pode imunizar sua medida contra o escrutínio judicial da maneira como a cláusula anulatória permite que os legislativos canadenses o façam. Apenas uma emenda geral ou revogação clara e expressa de um direito da Convenção pode criar tal imunidade e mesmo aí os tribunais podem ainda aplicar seu dever hermenêutico à questão de interpretar o que o Parlamento realizou.

Quanto à questão da petrificação, o governo declarou em seu Livro Branco que petrificar direitos da Convenção contra emenda ou revogação posterior por maiorias legislativas simples não era nem "necessário" nem "desejável”, visto que isso "não poderia ser reconciliado com nossas próprias tradições constitucionais, as quais permitem que qualquer lei do Parlamento seja emendada ou revogada por uma lei subsequente do Parlamento." ${ }^{114}$ Como acabamos de discutir, contudo, e diferentemente da LDDNZ, o efeito de expulsar a regra normal de revogação tácita por lei posterior conflitante (presumindo-se que os tribunais permitam isso) corresponde a petrificar de modo fraco os direitos da Convenção visto que, 
ao contrário da legislação ordinária, eles apenas podem ser expressamente revogados ou anulados. Até que isso ocorra, os direitos da Convenção continuam a ter plena força jurídica e os tribunais especificados possuem o poder de proferir uma declaração de incompatibilidade ante uma lei posterior conflitante exatamente da mesma maneira que acontece com uma lei anterior - mesmo de fato, como sugeri, diante de uma declaração parlamentar expressa de que o direito da Convenção deve ser anulado. ${ }^{115}$ Isso tem o efeito de impelir o Parlamento a declarar de maneira expressa sua intenção de emendar ou revogar um direito da Convenção, normalmente com uma declaração ministerial nesse sentido de acordo com a Seção 19. Os custos políticos de assim proceder são obviamente maiores do que os da revogação tácita que não está disponível e isso acrescenta alguma petrificação política à forma fraca de petrificação jurídica.

Finalmente, a questão da aplicação judicial nos leva a refletir sobre a característica individual mais inovadora da LDH: o poder concedido pela Seção 4 de se declarar uma lei parlamentar incompatível com um direito da Convenção que, porém, não traz consigo o poder de invalidar tal lei. Assim como a cláusula não obstante é uma invenção do Canadá, ${ }^{116}$ esse poder teve sua origem na LDH. Tanto em seu Livro Branco quanto durante o debate parlamentar acerca do projeto, o governo declarou repetidas vezes que havia decidido não conceder o poder do controle de constitucionalidade aos tribunais em virtude da importância que atribuía à soberania parlamentar. ${ }^{117}$ Todavia, mesmo sem o poder adicional de anular lei incompatível, o qual o governo afirmou que os tribunais não queriam e nem ele próprio tinha autorização de conceder, ${ }^{118}$ esse poder de questionar uma lei do Parlamento não tinha qualquer precedente na Grã-Bretanha fora do contexto jurídico da União Europeia ${ }^{119}$ e se colocava em tensão óbvia com o segundo ramo da teoria tradicional da soberania parlamentar. Ele de fato divide o poder do controle de constitucionalidade em duas funções separadas - decidir se existe um conflito entre um direito da Convenção e uma lei, e invalidar a última, caso exista - e conceder apenas o primeiro aos tribunais, enquanto deixa o segundo para o Parlamento. ${ }^{120}$ Mas mesmo que a LDH não exija do governo e do Parlamento ação reparadora em resposta a uma declaração, o que corresponderia a abrir mão da substância da segunda função, o governo declarou repetidamente que o resultado normal de uma declaração seria ou uma emenda ou uma revogação. ${ }^{121}$ Assim, o exercício por um tribunal do poder de declarar uma lei incompatível com um direito da Convenção, pelo menos, coloca em questão a "validade prolongada" da lei e, na maioria das vezes, obrigará as instituições políticas a emendá-la ou revogá-la.

Seja ou não essa engenhosa divisão da função do controle de constitucionalidade entre tribunais e Parlamento tecnicamente coerente com a soberania parlamentar, como alega o governo, o poder político que ela transfere às instâncias mais elevadas do judiciário é, indubitavelmente, um passo radical no contexto da cultura jurídica e constitucional britânica. Ao decidir se existe ou não incompatibilidade, os tribunais superiores realizarão inevitavelmente o mesmo tipo controvertido e contestado de tomada de decisão constitu- 
cional que os tribunais constitucionais praticam ao exercerem ambas as funções, algo que a versão britânica da separação de poderes tradicionalmente proibia.

Além disso, em termos de poder e cultura judiciais, o dever de interpretar a legislação primária em consonância com os direitos da Convenção deverá ser ao menos tão importante quanto o poder de declarar incompatibilidade, pois isso dá aos tribunais espaço substancial para reescrever leis do Parlamento empregando um método de interpretação amplo e direcionado a um propósito que é, mais uma vez, estranho à concepção britânica de função judicial, de acordo com a separação dos poderes. ${ }^{122} \mathrm{O}$ resultado de ambos é o de colocar, de forma direta e sem ambiguidade, o ônus sobre o Parlamento caso este deseje agir de forma incongruente com um direito da Convenção, um preço que o governo pode não estar disposto ou não ser capaz de pagar. A LDH, assim, envolve uma mescla e uma divisão de poderes muito interessantes entre os tribunais e os legislativos no que concerne à tutela aos direitos da Convenção. Ela é menos direta do que a cláusula anulatória canadense, no sentido de que o legislativo não deve apenas optar entre revogar ou substituir a decisão de um tribunal, pois não há decisão vinculante sem resposta parlamentar à declaração de incompatibilidade.

\section{AVALIAÇÃO DO MODELO DE CONSTITUCIONALISMO DA COMU- NIDADE BRITÂNICA}

O modelo norte-americano de constitucionalismo enxerga a supremacia legislativa e a efetiva proteção dos direitos fundamentais como mutuamente excludentes, exigindo que, em última instância, um sistema jurídico opte por um ou por outro. $O$ período transcorrido desde o final da Segunda Guerra Mundial é visto como um período no qual houve um crescimento enorme no constitucionalismo mundial, precisamente porque aconteceram mudanças muito difundidas nessa escolha básica, passando-se da supremacia legislativa para as declarações de direitos constitucionalizadas, uma vez que a tutela inadequada dos direitos fundamentais, que caracteriza a primeira, foi quase que imediatamente vista como inaceitável, dadas as experiências da Europa e do Japão.

Embora essa escolha fundamental entre duas opções diametralmente opostas seja, portanto, entendida como necessária, nunca se considerou que ela não tivesse um custo, uma vez que os problemas teóricos e práticos associados a cada uma das opções são bem conhecidos. O problema com a supremacia legislativa é, em resumo, o problema do majoritarismo legalmente ilimitado: nenhuma garantia formal e jurídica para os direitos fundamentais contra medidas devidamente promulgadas pelo parlamento, quaisquer que sejam os direitos legislados, consuetudinários, convencionais, culturais ou morais que o sistema jurídico possa em determinado momento reconhecer ou expressar.

Os problemas com uma declaração de direitos plenamente constitucionalizada estão muito bem documentados, nos Estados Unidos que a inventaram, nos muitos países que a rejeitaram, bem como naqueles poucos que o continuam a rejeitar pelas mesmas razões bási- 
cas. Em resumo, o veto judicial da legislação substitui o governo pelo povo por um governo de juízes (gouvernement des juges) com relação a muitas das mais importantes e controvertidas questões a serem resolvidas em uma comunidade política. Ele concede poder final de tomada de decisão sobre questões de princípio normalmente fundamentais e controvertidas, bem como sobre a questão do que é ou não direito nacional para o poder do governo que é o menos responsabilizável e que, caso seja de algum modo representativo, representa a soberania do passado sobre o presente.

Ao fazer isso, ele incapacita instituições representativas e desloca o autogoverno popular. Esse problema inerente fica ainda pior porque, qualquer que seja a teoria, essa palavra final raramente, se de tudo, é um ato puramente mecânico ou auto-evidente, mas deixa, para os tribunais que exercem o poder em ações e contextos específicos, discrição interpretativa substancial.

Assim como argumenta Jeremy Waldron, o judicial review não é um procedimento de tomada de decisão menos não-democrático do que uma ditadura por ter o povo votado a seu favor. ${ }^{123}$ Além disso, há muito se argumenta que o judicial review desencoraja e debilita a discussão legislativa e popular das questões de maior peso ao retirar a responsabilidade pela decisão final e enfraquece a capacidade política do povo ao substituir a responsabilidade popular pela judicial. ${ }^{124}$

Apesar desses problemas já amplamente reconhecidos, existe, acredito eu, um aspecto importante da verdadeira tensão entre o judicial review e a soberania popular cujo valor - por razões históricas - não é plenamente percebido nos Estados Unidos e que resultou em uma falta de compreensão plena da razão pela qual as reivindicações da supremacia legislativa foram, e continuam a ser, tão poderosas e imperativas para tantos outros países. Na Europa e em outros lugares, a supremacia legislativa é frequentemente entendida como a manifestação institucional distintiva da soberania popular, a noção de que todo poder político provém do povo e com ele permanece. Além disso, a soberania popular não é em geral percebida como um truísmo político vazio, pois ela foi tipicamente o resultado concreto e renhido de séculos de luta entre o povo, de um lado, e, do outro, um monarca (normalmente apoiado pela igreja e pela aristocracia) pela localização definitiva do poder. Ao longo dessa batalha, a soberania popular foi comumente institucionalizada no legislativo e o poder monárquico, no executivo ou no judiciário. A supremacia legislativa, assim, refletiu o triunfo histórico do povo contra as reivindicações de supremacia da Coroa e de uma reduzida elite política. ${ }^{125}$

Em compensação, nos Estados Unidos (produto de uma revolução colonial, mais do que de uma revolução popular, nesse sentido), a soberania popular foi considerada como certa de acontecer desde a fundação e, consequentemente, tende a parecer um truísmo, pois é difícil contemplar a hipótese de alternativas mesmo que, é claro, a revolução tenha sido lutada e a constituição projetada no contexto imediato de uma delas. Desta maneira, as instituições do governo não têm os mesmos históricos ou conjuntos de significados sociais. Sobretudo áridos, os parlamentos não são concebidos da mesma maneira como o órgão coletivo distintivo 
do povo. Em vez disso, eles são um dentre diversos órgãos do governo erigidos como um mal necessário e, em princípio, não menos estranhos ou "dos nossos" - e provavelmente mais perigosos - do que o poder executivo, ambos devendo ser vistos com suspeita pragmática e colocados uns contra os outros. ${ }^{126}$ Nesse contexto, impor limites jurídicos aos parlamentos não parece ser o mesmo que impor limites a "nós mesmos" ou o mesmo que transferir o poder para o povo; antes, parece semelhante a impor limites jurídicos ao executivo - ambos são limites que o povo impõe a seus líderes eleitos. É claro, a criação "desse contexto" foi um aspecto central do pensamento político revolucionário subjacente à Constituição. ${ }^{127}$

A nova "raça híbrida de declaração de direitos"128 que este artigo examina, foi projetada de forma consciente para prover uma nova solução para o antigo problema da incompatibilidade entre a supremacia legislativa e a tutela efetiva (isto é, judicial) dos direitos fundamentais.

A solução é nova porque rejeita a ideia de que as duas são necessariamente incompatíveis, ou seja, que apenas uma ou outra é possível. As novas declarações de direitos fundamentam-se na ideia de que é possível ter aquilo que há de essencial em ambas: a tutela judicial dos direitos fundamentais e a retenção pelo legislativo do direito de ter a última palavra sobre o que constitui o direito nacional. Ao contrário da visão tradicional originada da posição do Juiz Presidente Marshall de que não existe meio termo possível, ${ }^{129}$ elas clamam tê-lo encontrado e institucionalizado esse espaço analítico.

No restante deste artigo, primeiro abordarei mais profundamente a forma geral dessa solução. Explicarei então os benefícios e vantagens em potencial do novo modelo, questionarei se são exclusivos dele e avaliarei o impacto do novo modelo sobre as justificativas para o controle de constitucionalidade tradicional dentro do contexto da opção bipolar. Por fim, examinarei qual das três versões do novo modelo tem maior probabilidade de obter êxito no que diz respeito a proporcionar seus benefícios gerais e exclusivos.

\subsection{A NATUREZA DO NOVO MODELO}

O novo modelo de constitucionalismo tenta criar um meio termo coerente entre a tutela dos direitos fundamentais e a supremacia legislativa. As duas não são, necessariamente, mutuamente excludentes, como se presumia antes, porque é possível ter aquilo que cada uma possui de mais valioso sem abrir mão do essencial. De forma mais precisa, o modelo da Comunidade Britânica propõe que, a respeito de duas das três questões jurídicas que em conjunto definem as oposições polares - o status jurídico dos direitos fundamentais e a aplicação judicial -, existem posições intermediárias viáveis entre as tradicionais escolhas do tipo ou isto/ou aquilo.

Em primeiro lugar, as declarações de direitos da Comunidade Britânica rejeitam a proposição de que o status jurídico dos direitos fundamentais deva ou ser o de lei suprema ou, então, estar em pé de igualdade com o das leis legisladas ordinárias, situação que vincula o legislativo de modo apenas contingente, dependendo dos caprichos desta. Cada uma das 
três propõe um status jurídico intermediário. Os direitos da Carta, no Canadá, receberam um status menor do que o de lei suprema porque, embora costumeiramente sobrepujem todas as outras normas jurídicas, eles podem ser sobrepujados por maioria legislativa simples, estadual ou federal, sem serem emendados ou revogados. De acordo com a LDDNZ, o dever interpretativo atribuído aos tribunais neozelandeses significa que os direitos fundamentais sobrepujam leis potencialmente conflitantes, a menos que estas não possam ser interpretadas de modo a torná-las compatíveis. Nesse sentido, eles não são nem lei suprema, nem lei ordinária. Na Grã-Bretanha, o mesmo dever interpretativo, acrescido do poder judicial de declarar incompatibilidade, concede aos direitos da Convenção um status mais elevado do que o da lei ordinária, mas, ligeiramente mais baixo do que o de lei suprema.

A respeito da questão da aplicação judicial, os países da Comunidade Britânica deixam perceber que, de maneira semelhante, não é necessariamente verdade que os tribunais ou têm o poder final para invalidar leis conflitantes com direitos fundamentais, e consequentemente os legislativos são impotentes para reinstituí-las, ou então eles não têm o menor poder para aplicá-los. Mais uma vez, cada um dos três países da Comunidade Britânica produziu algo que se situa a meio caminho dessas duas posições: os tribunais têm uma função na aplicação dos direitos fundamentais que não corresponde aos plenos poderes do controle de constitucionalidade. Assim, no Canadá, os tribunais exercem o controle de constitucionalidade, mas estão sujeitos ao poder dos parlamentos para imunizar leis conflitantes ou reinstituir leis invalidadas. Na Nova Zelândia, os tribunais aplicam os direitos fundamentais não através da invalidação de leis, mas pela interpretação que dão a elas em consonância com os direitos, sempre que possível. Na Grã-Bretanha, os tribunais fazem o mesmo e, além disso, têm o poder de questionar uma lei conflitante declarando-a incompatível com um direito fundamental e provocando a expectativa (embora não a exigência jurídica) de que a lei será emendada ou revogada pelo legislativo.

Quanto à terceira questão jurídica, a petrificação, nem o Canadá nem a Nova Zelândia apresentam uma solução intermediária entre as tradicionais posições polares, mas a Grã-Bretanha, sim. No Canadá, os direitos da Carta somente podem ser emendados ou revogados por maiorias absolutas provinciais e nacional específicas, em sintonia com modelo norte-americano. ${ }^{130}$ Em contraposição, a LDDNZ pode ser expressamente emendada ou revogada por maioria legislativa simples e tacitamente revogada por lei posterior conflitante, embora, de acordo com o dever interpretativo, somente no caso de tal lei não poder ser interpretada de modo a evitar o conflito. De acordo com a LDH britânica, contudo, essa doutrina comum de revogação tácita não se aplica aos direitos da Convenção, significando que eles podem apenas ser emendados ou revogados de forma expressa, o que corresponde a uma forma limitada de petrificação, situada a meio caminho entre os polos. ${ }^{131}$

Dessas maneiras específicas, portanto, as declarações de direitos híbridas deixam perceber a possibilidade de que as reivindicações de supremacia legislativa e a efetiva tutela dos direitos fundamentais não sejam mutuamente excludentes, mas, antes, formem um continuum 
que vai da concepção mais absoluta de supremacia legislativa, em um polo, até o modelo norte-americano de uma declaração de direitos constitucionalizada, no outro.

Assim, movendo-se ao longo desse continuum a partir da extremidade da supremacia legislativa, a LDDNZ ocupa uma posição mais próxima desse polo, mas, ainda assim, um pouco afastada dele. Ela se distancia um pouco porque, embora não permita que a supremacia jurídica da legislação seja questionada de forma alguma, limita, através do dever interpretativo que impõe aos tribunais, as circunstâncias e a maneira como a legislação prevalecerá sobre a declaração de direitos. Ela concede aos tribunais um poder que não tinham anteriormente de acordo com os cânones ortodoxos de interpretação, para avaliar de maneira estrita as restrições aos direitos. A LDH ocupa, mais adiante no continuum, uma posição mais próxima do polo do modelo norte-americano do que aquele da LDDNZ, pois, além do dever interpretativo que também impõe aos tribunais, ela tanto impede a revogação tácita de suas disposições por legislação subsequente quanto garante aos tribunais mais elevados o poder de declarar formalmente uma incompatibilidade, no caso de haver um conflito que os tribunais não possam dissipar por meio de sua interpretação. Espera-se que tal declaração normalmente provoque uma resposta legislativa cujo resultado é a prevalência do direito sobre a lei conflitante. Finalmente, a Carta canadense posiciona-se intermediariamente entre o modelo norte-americano e a LDH, no sentido de que adota todos os elementos essenciais daquele, excetuando-se a anulação legislativa de direitos da Carta.

É claro, quaisquer que sejam as minúcias analíticas desse continuum a indicar a existência de um meio termo entre os dois polos, as recém-institucionalizadas posições ao longo dele serão atrativas ou plausíveis somente na medida em que equilibra e enfrenta os problemas percebidos em cada um dos dois polos. Alega-se novamente que aquilo que há de valioso e essencial tanto na tutela dos direitos fundamentais quanto na soberania parlamentar pode ser aproveitado simultaneamente sem seus problemas correlatos. Recapitulemos. O que há de valioso e essencial na tutela dos direitos fundamentais é obviamente a proteção jurídica adequada desses direitos. O problema associado a ela é que uma declaração de direitos plenamente constitucionalizada concede aos tribunais, em vez de aos parlamentos, a última palavra sobre o que é o direito nacional. De maneira contrária, o elemento mais essencial da soberania parlamentar é o fato de que o parlamento deveria receber poderes para ter essa última palavra, e o problema correlato é que, dessa maneira, a proteção adequada aos direitos fica impossível.

Em termos puramente jurídicos, portanto, cada um dos países da Comunidade Britânica agora protege direitos de maneira mais eficaz do que na época de seu regime original de supremacia legislativa plena e absoluta. O Canadá, pela instituição de uma declaração de direitos de anulação limitada; a Nova Zelândia, por intermédio de uma declaração de direitos exclusivamente interpretativa; e a Grã-Bretanha, com a mescla das duas. Por outro lado, cada um também conserva o elemento fundamental da soberania parlamentar, do modo a vêem, assegurando que a legislatura possa, caso queira, ter a última palavra sobre o que é 
o direito nacional. No Canadá, pelo exercício da anulação; na Nova Zelândia, por meio da legislação que expressamente, ou por inferência livre de ambiguidade, limite direitos; e na Grã-Bretanha, primeiro por limitação expressa e depois pela recusa de emendar ou revogar uma lei após uma declaração judicial de incompatibilidade.

\subsection{COMPARAÇÃO ENTRE OS MODELOS DE CONSTITUCIONALISMO DA CO- MUNIDADE BRITÂNICA E DOS ESTADOS UNIDOS}

Quais são os benefícios e vantagens em potencial deste novo modelo? São eles exclusivos deste ou os mesmos resultados podem ser alcançados dentro do modelo norte-americano? Qual luz, se alguma, esse novo modelo lança sobre as justificativas existentes para o modelo norte-americano visto dentro do contexto da tradicional escolha bipolar?

\subsubsection{Os benefícios potenciais do novo modelo}

Analítica e institucionalmente, o maior impacto e a maior contribuição do novo modelo é abrir um leque de possibilidades intermediárias onde previamente, pensava-se, não existia nenhuma. A nova questão pode passar a ser, em vez de saber qual das duas posições polares deveremos ocupar, onde nos posicionar no espectro.

Com quase toda certeza, pode não haver uma resposta global para essa questão, pois, em última instância, a escolha deverá depender, ao menos em parte, das preferências normativas entre os valores que provavelmente são cultural e historicamente específicos. Mas, mesmo assim, o novo modelo poderá dar três importantes contribuições para essa decisão.

Primeiro, na medida em que um sistema jurídico escolhe uma das duas posições opostas pelos méritos de cada uma, embora consciente da existência dessas novas opções, porque prefere o controle de constitucionalidade tradicional ou por estar vinculado à versão mais forte da supremacia legislativa, então sua escolha é muito mais autoconsciente e, em consequência, mais transparente. Segundo, na medida em que a escolha não contou com informações completas como essas, mas teve como premissa a noção de que existem apenas duas posições polares, a solução híbrida da Comunidade Britânica promete reabrir e tornar mais complexas questões de uma forma saudável. Terceiro, a evidência empírica do registro atual das experiências da Comunidade Britânica com a tutela de direitos pode suplementar e ajudar a informar a questão normativa de qual escolha entre os dois valores é apropriada e necessária. Até aqui, a preocupação no registro canadense é oposta à de saber se se protege adequadamente a soberania parlamentar. Na Nova Zelândia, surgiu uma "nova cultura de direitos" em torno da Declaração de Direitos, embora isso tenha levado em conta principalmente o controle de constitucionalidade dos atos administrativos, o que não levanta a questão de sua incompatibilidade da mesma maneira que a da legislação. Na Grã-Bretanha, é obviamente muito cedo para concluir algo. 
Além de criar opções onde previamente elas não existiam, o modelo da Comunidade Britânica indica quatro benefícios específicos e tangíveis em comparação com a posição polar do modelo norte-americano. Quais sejam: (a) abordar o problema da debilitação legislativa e popular que preocupou muitos observadores do judicial review tradicional; (b) fazer com que o discurso sobre direitos constitucionais se transforme, passando de um monólogo judicial para um diálogo interinstitucional mais rico e mais equilibrado; (c) aprimorar a legitimidade do papel dos tribunais por intermédio da criação de uma divisão de trabalho parcial a respeito da tarefa comum, e talvez inevitável, de se equilibrar, na jurisdição constitucional, direitos individuais e imperativos da política pública e (d) reduzir, se não eliminar, a tensão entre a tutela judicial dos direitos fundamentais e a tomada de decisão democrática. Analisemos agora, um por um, esses benefícios.

Ao menos desde que James Bradley Thayer identificou a questão no final do séc. XIX, tem sido plenamente reconhecido que um dos maiores custos institucionais do controle de constitucionalidade é que este tende a debilitar tanto o exame legislativo de matérias de elevados princípios quanto a responsabilidade popular pela proteção dos direitos através do voto secreto. ${ }^{132}$ Isso porque, onde os legislativos não têm a responsabilidade final, existe uma tendência, tanto da parte daquelas quanto da do eleitorado, de deixar questões de constitucionalidade e de direitos para os tribunais. ${ }^{133}$ Com o tempo, essa desvalorização do discurso legislativo pode não apenas minar a capacidade de autogoverno do povo, como também ser um fator importante no deslocamento do interesse público para o interesse privado, o que, na opinião de muitos, caracteriza e desmoraliza a política contemporânea.

Ao conceder aos parlamentos o poder de ter a última palavra sobre o que é a lei, o modelo da Comunidade Britânica promete quebrar esse círculo vicioso e revitalizar o debate político legislativo e popular. Seja exercendo seu poder de anular a Carta, seja respondendo a uma declaração de incompatibilidade ou legislando claramente de uma maneira que não possa ser interpretada de forma congruente com a declaração de direitos, os legislativos contam com novos e poderosos incentivos para não delegar a responsabilidade da consideração de matéria de princípios aos tribunais. $\mathrm{O}$ exame pelos tribunais deixa de ser necessariamente o exame final. Por outro lado, o exercício desse poder legislativo provavelmente não será rotineiro, mas, empreendido sob os holofotes da publicidade - iniciado por declarações ministeriais, decisões judiciais ou pela anulação - e presumivelmente carregará um pesado fardo político de justificativa quanto às razões pelas quais os direitos individuais não deveriam prevalecer. Desta forma, a expectativa é a de que os legislativos serão forçados a enfrentar e a deliberar de uma maneira baseada em princípios sobre as mesmas controvérsias e determinadas questões jurídica, políticas e morais que os tribunais enfrentam no contexto da jurisdição constitucional. ${ }^{134}$

Fortemente ligado a isso está o fato de que o monopólio e o monólogo judicial, quanto ao significado e ao âmbito de aplicação dos direitos constitucionais, podem ser substituídos pelo diálogo interinstitucional entre os tribunais e os parlamentos, o qual aprimoraria a qualidade e as dimensões da análise constitucional, pois o problema da debilitação não é apenas 
um problema auto-induzido pelos legislativos. Dentro da teoria da supremacia judicial, a qual concede ao judiciário a última palavra, os tribunais frequentemente se ressentem das tentativas empreendidas pelos parlamentos de participar na tarefa da interpretação constitucional, declarando ser isso uma usurpação de sua autoridade. ${ }^{135}$

Embora analiticamente distintas, a supremacia judicial leva com facilidade à exclusividade judicial e ao desrespeito institucional pelas opiniões constitucionais dos poderes eleitos do governo. Isso pode também ocasionar a superjudicialização do discurso constitucional e a consequente extinção de formas de constitucionalismo popular. ${ }^{136} \mathrm{O}$ diálogo compulsório, a concorrência e a responsabilidade conjunta entre os tribunais e os parlamentos, que o modelo da Comunidade Britânica almeja assegurar, prometem acrescentar uma nova dimensão e perspectiva à tarefa da interpretação constitucional e também enriquecer a iniciativa.

Esse diálogo pode também levar, quanto à análise constitucional, a uma divisão de trabalho entre os tribunais e os legislativos que seja melhor e mais apropriada do que aquela existente em um sistema de supremacia judicial. Raramente são os direitos constitucionais absolutos, estejam ou não as limitações expressas presentes no texto. ${ }^{137}$ Nesse contexto, a jurisdição constitucional exige tanto a especificação dos limites permissíveis quanto a determinação de terem ou não sido excedidos os limites em qualquer caso específico. Na medida em que a conclusão da segunda tarefa envolve, como de costume, ${ }^{138}$ avaliar tanto a importância do objetivo legislativo quanto a racionalidade, a necessidade ou a proporcionalidade da lei questionada, existe com frequência uma sensação de que os tribunais correm o risco de se extraviarem para o terreno da política e da preferência.

O modelo da Comunidade Britânica oferece a possibilidade de uma divisão de trabalho na qual os tribunais têm efetivamente a última palavra na primeira tarefa, mais parecida com lei, de especificar o padrão constitucional, e os legislativos, na segunda, a aplicação desse padrão. Isso porque os parlamentos talvez estejam mais propensos a dar conta de seu fardo político ao fornecerem uma justificativa não pela via de contestação do estabelecimento, por um tribunal, do âmbito de aplicação e do conteúdo de um direito, nem pela via do anúncio de que o estão simplesmente anulando, mas porque discordam do tribunal quanto à função, à primeira vista menos inerentemente "judicial", de se pesarem as razões para se limitar o direito em um caso específico. Nesse processo, os tribunais podem na verdade ficar mais encorajados a interpretar o conteúdo e o âmbito de aplicação dos direitos, sabendo que não terão necessariamente a responsabilidade final de restabelecer o equilíbrio ou de rejeitar os pontos de vista majoritários. ${ }^{139}$ Isso pode diminuir a percepção de que os tribunais estão empenhados na política discricionária, o que, por sua vez, pode ocasionar tanto uma tomada de decisão constitucional melhor e mais apropriada, quanto uma maior atribuição de legitimidade às funções dos tribunais.

Finalmente, o novo modelo é, claro, projetado de forma autoconsciente para proporcionar uma nova solução institucional ao antigo problema da tensão entre judicial review e democracia. Suas alegações são as de que a proteção judicial de direitos não precisa ser incompatível com a essência da supremacia judicial, a qual exige que os legisladores tenham 
o poder da última palavra. Essa é, obviamente, a maneira mais direta de "dissolver" a dificuldade contramajoritária: o judicial review fica sujeito à anulação majoritária de uma das três formas diferentes proporcionadas. Analisarei o impacto dessa solução sobre as justificativas existentes.

\subsubsection{Esses benefícios podem ser alcançados sem que se rejeite o modelo norte-americano?}

Como indiquei logo de início, a disciplina do direito constitucional comparado está muito ocupada com as variações institucionais exibidas entre muitos países que adotaram as características essenciais do modelo norte-americano de constitucionalismo a partir de 1945.

Algumas dessas variações foram projetadas para diminuir a tensão entre a supremacia judicial e a legislativa por intermédio da criação de pontes procedimentais e institucionais por sobre o abismo substantivo que as separa. $O$ mesmo objetivo foi tentado nos Estados Unidos pelo mecanismo característico da autorregulamentação: os tribunais impondo restrições ao seu próprio exercício do poder do judicial review. Podem os benefícios potenciais do modelo da Comunidade Britânica serem alcançados, através de variações e reformas dessa espécie, dentro do modelo norte-americano e, sobretudo, sem que se afaste da teoria da supremacia judicial?

Uma tentativa procedimental popular para contrabalançar a reconhecida tensão entre supremacia constitucional e legislativa a respeito da proteção de direitos é aumentar o papel do legislativo na nomeação de juízes que exercitem o judicial review. Embora os tribunais detenham substantivamente a última palavra sobre o que é a lei, característica central do modelo norte-americano, alcança-se certo grau de reconciliação procedimental ao conceder ao parlamento a última palavra sobre quem deve exercer esse poder sobre suas promulgações. Na Europa, tanto o característico tribunal constitucional singular e especializado quanto o método de selecionar seus membros têm como premissa a negação da justificativa dada pelo Juiz Presidente Marshall para o judicial review como parte normal e rotineira da função judicial regular. ${ }^{140}$ Assim, o sistema ordinário de nomeação e promoção judicial - uma função puramente executiva e amplamente burocrática desempenhada pelo Ministro da Justiça ou seu equivalente ${ }^{141}$ - é substituído por uma função mais abertamente política na qual os membros do tribunal constitucional são selecionados ou de maneira direta apenas pelo legislativo, com o devido e declarado respeito à filiação partidária dos juízes, ou com as duas casas do legislativo mais o executivo selecionando um terço cada. ${ }^{142}$

Em contraposição, o processo de nomeação nos Estados Unidos é muito menos direcionado à reconciliação procedimental com a supremacia legislativa, uma vez que os juízes federais são indicados pelo chefe do poder executivo (eleito diretamente), estando o papel legislativo limitado à aprovação ou rejeição pelo Senado por meio de voto majoritário. Um segundo mecanismo procedimental correlacionado, comum na Europa, é ter, em lugar da vitaliciedade, um mandato com duração fixa e não renovável para o tribunal 
constitucional, a fim de assegurar uma participação legislativa mais frequente na composição de seus membros. ${ }^{143}$

Embora a seleção pelo legislativo de juízes constitucionais e os mandatos fixos possam talvez reduzir a tensão entre a supremacia constitucional e a legislativa, elas não solucionam sua principal fonte. Esta é menos a questão procedimental de seu método de nomeação do que a questão substantiva de sua função. Aqui é importante distinguir, como questões separadas, o judicial review como procedimento não democrático de tomada de decisão e a reivindicação de supremacia legislativa. Mesmo a eleição direta de juízes (como acontece em nível estadual nos Estados Unidos) não satisfaria essa reivindicação. Um tribunal constitucional com membros nomeados plena e diretamente pelo legislativo continua não equivalendo a um comitê legislativo, em virtude da diferença crítica de que o parlamento não tem poder para anular suas decisões, nem a última palavra. Além disso, não está óbvio que a seleção legislativa pode ou poderia proporcionar os potenciais benefícios. Exceto talvez pela questão específica das nomeações judiciais, não fica claro como isso reduz o problema da debilitação ou cria diálogo interinstitucional e, na medida em que o faz, surge a ameaça potencial a outro valor sistêmico importante: a independência do judiciário.

Isso pode acontecer sobretudo naqueles poucos sistemas em que os juízes têm mandatos fixos e renováveis, mas poderia também surgir dentro do arranjo mais comum de mandatos fixos e não renováveis. ${ }^{144}$ Em compensação, a grande inovação das declarações de direito híbridas é instituir, quanto à responsabilidade pela proteção dos direitos, uma divisão oficial de trabalho entre os tribunais e os parlamentos que não depende de obrigações ou incentivos criados pelo sistema de nomeação.

A teoria do judicial review mínima, advogada inicialmente em fins do séc. XIX por James Bradley Thayer ${ }^{145}$ e adotada em graus diversos por seus protegidos e por outros membros da Suprema Corte dos Estados Unidos durante o séc. XX, ${ }^{146}$ é a principal teoria da autorregulamentação. $O$ fato de esta teoria ter sido expressamente inserida nos textos constitucionais da Suécia e da Finlândia demonstra, contudo, que a natureza autorregulamentatória do judicial review mínima não é essencial. ${ }^{147}$ De acordo com a fórmula proposta pelo próprio Thayer, apenas quando um legislativo tiver cometido um "erro muito claro" a respeito da constitucionalidade da lei por ela promulgada, "tão claro que não se presta a questionamento racional", deveria um tribunal derrubá-la. ${ }^{148}$ Essa regra de deferência representa tanto uma tentativa procedimental para justificar o judicial review contrabalançando sua notória tensão com o processo de tomada de decisão democrático, quanto uma tentativa de enfrentar uma de suas consequências institucionais, o problema da debilitação democrática, limitando o alcance do poder. ${ }^{149}$

A visão de Alexander Bickel de que, a respeito do judicial review, os tribunais deveriam exercer "virtudes passivas" 150 é uma outra expressão desse ideal limitativo, como também o são presunções mais fortes e genéricas de constitucionalidade. Em certo sentido, a teoria opta pelo judicial review de jure e pela supremacia legislativa de facto, o limite respectivo de cada uma dependendo do critério específico de "erro claro". A formulação alternativa de 
Thayer de "para além de dúvida razoável" a qual, assim como sua contraparte penal, parece exigir unanimidade, cria obviamente uma presunção muito forte de constitucionalidade. ${ }^{151}$

Uma comparação entre as declarações de direitos híbridas revela que o controle de constitucionalidade mínimo pode ser uma solução inferior a respeito dos valores polares. Com relação à proteção de direitos em um contexto no qual a discordância radical, embora razoável, na jurisdição constitucional é endêmica, o resultado estaria propenso a ser sub-aplicação e sub-proteção substanciais - muito mais do que em qualquer das três versões de declarações de direitos híbridas. Isso ilustra mais uma vez a colocação geral de que a efetividade da tutela de direitos não é simplesmente uma função de seu status jurídico. Em essência, a teoria minimalista inverte o dever interpretativo imposto aos tribunais no Reino Unido, na Nova Zelândia e conforme a DDGC no Canadá, pois exige que os tribunais interpretem a Constituição como congruente com a lei sob contestação sempre que não haja "erro claro", em vez de exigir que se interprete a lei à luz da declaração de direitos. Por outro lado, contudo, o controle de constitucionalidade mínimo ainda violaria a soberania parlamentar sempre que não justificasse seu exercício, uma vez que o parlamento não tem poder jurídico para insistir que seu erro claro se sustenta, embora este não seja o tipo mais forte de caso para uma anulação. Essa característica "tudo ou nada" da teoria minimalista significa que pouco equilíbrio real entre os dois valores é alcançado e, dessa perspectiva, ela parece inferior à declaração de direitos híbrida.

Quanto à debilitação democrática, e ao diálogo interinstitucional também, uma forte presunção de constitucionalidade pode simplesmente criar incentivos inadequados para o legislativo ou o povo tomar parte nos desejados debates baseados em princípios em comparação com o modelo da Comunidade Britânica. Em vez de se sentir obrigada a conduzir tal debate, o parlamento pode simplesmente deixá-lo com os juristas para que apresentem as alegações plausíveis a favor da constitucionalidade, se e quando chegar a hora. E, sem uma a invocação legislativa expressa de seu poder de substituir ou anular direitos individuais, os eleitores podem não estar avisados ou não ter informações suficientes para provocar seus interesses. ${ }^{152}$

Uma possibilidade final, ao menos dentro da versão estadunidense do modelo norte-americano, é a de que alcançar o mesmo resultado de um mecanismo legislativo anulatório é algo que, na verdade, já estava entre os poderes enumerados do Congresso de controlar a jurisdição dos tribunais federais, incluindo a Suprema Corte. ${ }^{153}$ Pode-se argumentar que, interpretado de maneira ampla, esse poder poderia ser utilizado para limitar ou mesmo destruir o poder do judicial review. Mas, a não ser pelos fatos de que (a) o poder jurisdicional do Congresso nunca foi empregado ou compreendido dessa maneira, como notou Mark Tushnet nesse contexto, ${ }^{154} \mathrm{e}$ de que (b) provavelmente haveria sérias dificuldades constitucionais para assim proceder, dado o status constitucional inerente ao judicial review como visto por Marshall, isso não significaria alcançar os mesmos benefícios dentro do modelo norte-americano; mas, abandonar esse modelo em favor de uma das duas alternativas. 
A abolição pelo Congresso do judicial review simplesmente promulgaria a soberania parlamentar plena e uma utilização mais limitada e particularizada do poder congressional criaria mais uma versão do modelo da Comunidade Britânica, conferindo ao legislativo poder para ter a última palavra. Muito provavelmente, seu caráter opaco, altamente técnico e indireto ${ }^{155}$ estaria menos propenso a proporcionar os benefícios associados aos outros três métodos, mais abertos e explícitos. Todavia, novamente, central aqui não é saber se os Estados Unidos poderiam mudar sua prática constitucional corrente e adotar o modelo da Comunidade Britânica - por proposição parlamentar ou emenda constitucional -, mas, saber se podem ou não colher os benefícios desse modelo sem que o façam.

\subsubsection{O impacto do novo modelo sobre as soluções existentes para o problema do judicial review}

Como vimos, um dos benefícios teóricos óbvios do novo modelo é o de oferecer uma solução direta para os problemas democráticos associados ao controle de constitucionalidade, concedendo ao poder majoritário do governo, não aos tribunais, a palavra final. Uma justificativa apresentada para o controle de constitucionalidade não aborda essa questão, mas, em vez disso, conta com a superioridade normativa percebida na proteção de direitos plenamente constitucionalizada, independentemente de quaisquer custos democráticos ou incongruências. ${ }^{156}$ Mas outras tentam encarar o problema de frente, tentando "dissolvê-lo" ao alegar que o controle de constitucionalidade tradicional é congruente com a democracia e o autogoverno popular, podendo até promovê-los. Tais teorias foram interpretadas, é claro, no contexto da escolha polar: ou supremacia judicial ou nada de proteção judicial.

A questão que está agora sendo considerada é a de saber em que medida essas teorias continuam plausíveis diante da nova alternativa de uma função judicial intermediária e menos poderosa. Nesta seção, eu avaliarei as três mais influentes justificativas desse tipo.

A primeira delas é a teoria da "re-aplicação da representação" associada a John Hart E $1 y^{157}$ e à nota de rodapé número quatro de Carolene Products, ${ }^{158}$ mas cujas origens podem ser identificadas como remontando, ao menos, à opinião do Juiz Presidente Marshall em McCulloch v. Maryland. ${ }^{159} \mathrm{O}$ argumento é o de que a supremacia judicial não apenas é compatível com a democracia representativa e a soberania popular, mas, na verdade, aprimora ambas quando o seu exercício é limitado ao aperfeiçoamento do processo democrático através da aplicação daqueles direitos que se relacionam com uma participação política plena e igualitária. Estes incluem os direitos ao voto, à liberdade de expressão e à não discriminação.

No contexto especificamente comparativo do novo modelo no qual a estamos considerando, parece haver dois problemas com essa teoria. Primeiro, por mais que se possa interpretar a Constituição dos Estados Unidos como predominantemente portadora de direitos procedimentais de participação democrática, essa não é uma explicação plausível para os direitos fundamentais contidos nas constituições redigidas logo após a Segunda Guerra Mundial e, assim, não pode fornecer uma justificativa para o controle de constitucionalidade 
pleno quanto às muitas disposições substantivas que contêm. ${ }^{160}$ Segundo, o abismo existente entre a soberania popular e a supremacia legislativa, com o qual essa teoria conta, vai em direção oposta à tradição européia pelas razões apresentadas acima. De forma particular, embora não exclusiva, o objetivo de se aprimorar os procedimentos democráticos por meio da incapacitação de instituições democráticas parece paradoxal nesse contexto. Em contraposição, as declarações de direitos da Comunidade Britânica protegem tanto os direitos procedimentais quanto os substantivos, mas de modo que não incapacitam completamente as instituições representativas em nome de seu próprio aperfeiçoamento.

A segunda teoria faz um apelo mais direto ainda ao povo como superior à instituição que alega representá-lo e expressar a soberania popular. Essa teoria minimiza não o exercício do judicial review, como acontece em Thayer, mas a concepção daquilo que os juízes que a exercitam estão fazendo. Tendo como fonte as defesas do judicial review fornecidas pelo Juiz Presidente Marshall e por Alexander Hamilton, ${ }^{161}$ o argumento se pauta na fonte e na autoria democrática da Constituição por Nós, o Povo e vê a tarefa dos tribunais como a de simplesmente proteger e aplicar seu texto contra o parlamento, com pouca contribuição independente. Além disso, algumas versões desse argumento prescrevem um método de interpretação constitucional que adere estritamente ao texto que o povo promulgou para limitar o legislativo, ou então à sua intenção original - ou à dos redatores. ${ }^{162}$ Bruce Ackerman dinamizou esse venerável argumento ao postular uma função judicial mais complexa de síntese interpretativa de intervenções sucessivas por Nós, o Povo ao longo do tempo. ${ }^{163}$ Os problemas gerais com essa solução são bastante conhecidos. Primeiro, ela é motivada por justificativa, mais do que por observação, e não descreve de forma plausível o verdadeiro processo de jurisdição constitucional. Mesmo com o texto mais minuciosamente redigido que se possa imaginar, esse processo é necessariamente menos mecânico e concede maior discrição aos tribunais do que a estrutura da solução pareceria permitir.

Tal discrição, embora democraticamente concedida, fica em grave tensão com o princípio do autogoverno popular e enfraquece a ideia de judicial review como uma simples estratégia de pré-comprometimento pelo povo soberano. ${ }^{164}$ Segundo, dada a petrificação dos direitos fundamentais e a consequente dificuldade de emenda, ela dá primazia não à atual soberania popular, mas àquela do passado, sem justificativa adequada. Em contraposição, uma marca de autenticidade da soberania parlamentar tradicional é a teoria de que os legislativos passados não podem vincular os futuros, assegurando que as atuais maiorias gozem da plena soberania de seus predecessores. Novamente, no contexto comparativo, existe o problema adicional de que essa solução tem como premissa a concepção norte-americana de parlamento como desprovido de uma conexão distintiva com o povo e a soberania popular. ${ }^{165}$ Isso empresta uma plausibilidade democrática à reivindicação de que os tribunais são os verdadeiros guardiões da soberania popular, possibilidade essa que não se encontraria em qualquer outro lugar. Em resumo, ela deixa de levar o parlamento a sério o suficiente como manifestação institucional da soberania popular. 
Ao colocar esses problemas gerais para um lado, a teoria em si, como outras examinadas, foi composta no contexto da escolha bipolar: ou controle de constitucionalidade tradicional ou supremacia legislativa plena. O desafio que o novo modelo da Comunidade Britânica coloca é o de saber se os limites que ele cria para o poder judicial podem harmonizar-se melhor com a estrutura subjacente do apelo que faz à soberania popular. Em outras palavras, pode o papel do judiciário em tutelar direitos fundamentais ser um freio mais apropriado sobre o parlamento, em vez de sobrepujá-lo, forçando-o a pensar em termos sérios e com base em princípios antes de exercer o seu poder da última palavra? $\mathrm{O}$ abismo apontado entre a soberania popular e a legislativa pode ser preenchido com informação e responsabilidade eleitoral. $\mathrm{O}$ papel dos tribunais torna-se o de alertar plenamente o povo, chamando sua atenção para leis potencialmente inconstitucionais, de modo que o legislativo possa responder de modo pleno por elas.

Finalmente, existe a justificativa para a escolha do modelo norte-americano associada a Alexander Bickel. ${ }^{166}$ Esta destaca a divisão de função e as habilidades relativas dos tribunais e dos parlamentos de modo que a necessária discussão dos princípios gerais é melhor empreendida por aqueles, pois somente os tribunais têm a independência, o tempo e a motivação para tanto. Contudo, da perspectiva thayeriana, mesmo se verdadeira, essa capacidade judicial para discutir elevados princípios não é uma variável puramente independente, mas, ao menos em parte, é um produto do próprio judicial review. Ela assume a consequência do judicial review como uma justificativa para ela.

Uma das vantagens potenciais mais importantes das declarações de direitos híbridas é a de que elas tentam transcender qualquer divisão de função ao criar fortes incentivos para que os legislativos passem a se envolver com modos constitucionais de discussão. Assim, no Canadá, os parlamentos devem decidir se vão exercitar o poder anulatório; na Nova Zelândia, se vão fazer com que uma lei seja impossível de ser interpretada de maneira congruente com direito relevante e no Reino Unido, como responder a uma declaração de incompatibilidade. Nesse sentido, o argumento de Bickel pode promover avanços: os parlamentos podem não proceder de acordo com princípios em grande parte porque eles não têm a responsabilidade da última palavra.

\subsection{QUAL DAS TRÊS VERSÕES DO MODELO DA COMUNIDADE BRITÂNICA TEM MAIOR PROBABILIDADE DE PROPORCIONAR SEUS BENEFÍCIOS DIS- TINTIVOS?}

Como o continuum esboçado acima deixa claro, embora as declarações de direitos em todos os três países da Comunidade Britânica exemplifiquem o novo modelo para equilibrar as reivindicações de soberania parlamentar e as de tutela dos direitos fundamentais, mais do que optar por uma delas, cada uma das declarações alcança o equilíbrio entre as duas posições de forma diferente. Assim, embora cada uma preserve o elemento fundamental da soberania 
parlamentar enquanto protege direitos fundamentais, cada declaração dá um peso diferente para um dos dois valores. A respeito dos direitos, todas concedem maior proteção aos direitos fundamentais do que o país o fazia anteriormente, variando da proteção jurídica mais forte no Canadá, passando por uma proteção menor no Reino Unido, até a mais fraca na Nova Zelândia. De maneira contrária, em termos de reduzir o problema democrático associado a esse dado nível de proteção aos direitos, cada país prescreve que a decisão final sobre o que é a lei pode ser tomada pelo legislativo, mas a maneira pela qual ela o pode fazer significa que a Nova Zelândia é o país que mais reduz o problema, em seguida o Reino Unido e o Canadá é aquele que menos o faz. Dito de outra maneira, formalmente, o Canadá parece se afastar mais da soberania parlamentar absoluta e cria os maiores custos políticos para o parlamento que busca exercer seu poder de anular direitos, o Reino Unido vem em seguida e, por último, a Nova Zelândia. Qual desses três representa a versão mais forte da nova solução híbrida? Qual tem maior probabilidade de proporcionar seus benefícios?

Deixe-me colocar duas questões entre parênteses. Primeiro, assim como acontece com os méritos do novo modelo como um todo, a resposta geral pode, para muitos, depender em última instância de um maior comprometimento normativo para com um dos dois valores. Assim, se a tutela judicial tradicional de direitos fundamentais for considerada mais importante do que quaisquer custos democráticos que acarreta, então o exemplo canadense parecerá a priori mais atrativo do que os outros dois e o modelo norte-americano, mais atrativo do que o do Canadá. Segundo, o equilíbrio formal e jurídico contido nas diversas declarações de direitos pode não ser a variável mais importante para decidir se o equilíbrio entre os dois valores foi alcançado na prática e em que quantidade. Como discutido no item 3, por exemplo, as experiências do Canadá e da Nova Zelândia ilustram claramente o fato de que o contexto, a cultura jurídica e política e a contingência histórica desempenham também, cada um, o seu papel. Assim, as juridicamente semelhantes DDGC e LDDNZ alcançaram resultados bastante diferentes na prática em termos de proteção judicial de direitos e o comprometimento pretendido, entre os dois polos que a Seção 33 da Carta se destinava a implementar, ficou neutralizado por convenção constitucional.

Tanto da perspectiva de abordar o problema da debilitação legislativa e popular quanto da de criar o diálogo interinstitucional entre os tribunais e os parlamentos, o método mais favorável para possibilitar que um legislativo tenha a última palavra sobre o que é a lei seria aquele que (a) aumente os custos políticos da violação de direitos forçando o enfrentamento direto e deliberado da questão de princípio envolvida quando ele escolher exercer esse poder, mas que (b) não os aumente a ponto de tornar esse poder impraticável. Infelizmente, tanto a solução canadense da Seção 33 quanto a LDDNZ provavelmente deixam a desejar quanto ao primeiro ponto.

A respeito do Canadá, o primeiro requisito indica que a anulação legislativa não deveria ser utilizada rotineiramente ou de modo muito direto, do contrário, ela deixaria de provocar a elevada conscientização desejada. A decisão em Ford permitindo tanto anulações omnibus quanto padrão faz exatamente isso. É claro, Ford poderia ter sido decidido de maneira dife- 
rente, ${ }^{167}$ mas mesmo se o argumento de especificidade máxima tivesse sido aceito de modo que (i) cada lei devesse conter sua própria disposição anulatória e (ii) tal disposição devesse expressar em palavras quais direitos específicos estão sendo anulados e como, isso ainda permitiria anulações preventivas (o que não constituía questão no caso).

Pode-se argumentar que mesmo tais anulações não conseguiriam ainda aumentar suficientemente os custos políticos. A natureza inerentemente hipotética de violações futuras de direitos conforme uma lei imunizada pode não concentrar tão adequadamente as atenções quanto as violações concretas reais após julgadas por um tribunal. Anulações preventivas, assim, privam o debate legislativo e popular da valiosa participação de um ponto de vista judicial bem refletido sobre a questão relevante.

De acordo com a LDDNZ, ou prevalecem os direitos fundamentais em conformidade com o dever interpretativo dos tribunais, ou os tribunais consideram que uma lei (anterior ou subsequente) não pode ser interpretada de modo congruente com os direitos, caso em que prevalece a lei. Juridicamente, a soberania parlamentar tradicional é fortemente protegida. Os tribunais não têm poder para questionar leis que decorram de proposição parlamentar e mesmo leis anteriores consideradas em conflito com a declaração de direitos sobreviverão e não serão tacitamente revogadas por aquela. Institucionalmente, contudo, Andrew Butler argumentou que um grande problema com a LDDNZ é que ela concede responsabilidade máxima aos tribunais para proteger tanto os direitos fundamentais quanto a soberania parlamentar. ${ }^{168}$ De acordo com Butler, isso se dá porque a única questão em tela diz respeito à interpretação da lei e os tribunais são os intérpretes finais da lei. Nesse contexto, eles devem resolver as reivindicações rivais de direitos fundamentais e de soberania parlamentar por si próprios, sem que possam contar com o parlamento exercendo sua própria reivindicação de soberania através de um mecanismo especial como no Canadá e no Reino Unido. Além disso, argumenta ele, mesmo quando o legislativo promulga uma medida a despeito de uma declaração de incongruência pelo Procurador-Geral em consonância com a Seção 7, esta também está, em última instância, sujeita à interpretação do tribunal, e pode bem haver razões plausíveis para não se considerar que exista conflito. ${ }^{169}$

Se existe um problema com a LDDNZ em termos de colher todos os benefícios do novo modelo, não estou convencido de que isso se dê porque o legislativo pode sempre responder a uma interpretação de um tribunal que a desagrade e emendar a lei relevante de maneira a fazer com que sua intenção sobrepuje um direito não controvertível e à prova de interpretação. De fato, como discutido acima, esse cenário parece exemplificar o método distintivo pelo qual declarações de direitos interpretativas protegem ambos os valores. $O$ problema parece ser antes o oposto, e é semelhante àquele da anulação canadense na prática: a utilização preventiva pelo parlamento desse poder. Onde o legislativo deixa explícita sua intenção de expulsar um direito no momento de sua promulgação inicial, em vez de valer-se de uma emenda em resposta a uma decisão de um tribunal com a qual discorda, existe a probabilidade de que os custos políticos sejam bem baixos. Assim como acontece com a anulação preventiva no Canadá, o legislativo não será forçado a debater à luz da publicidade criada 
por uma decisão judicial contrária ${ }^{170}$ e a valiosa participação do ponto de vista do tribunal quanto ao assunto estará ausente. A declaração pelo Procurador Geral em conformidade com a Seção 7, embora útil, pode bem ser insuficiente para esses propósitos.

A LDH trata diretamente desse problema. Ela não permite qualquer uso preventivo de uma anulação legislativa (seja de rotina ou específica), pois as disposições de ordem reparadora apenas entram em jogo de maneira reativa, isto é, após uma declaração judicial de incompatibilidade. Falta ao Parlamento o poder de um legislativo canadense ou neozelandês para imunizar suas ações contra posterior questionamento judicial. Não importa o quão expressamente o Parlamento declare seu desejo de violar um direito da Convenção em uma dada lei, os tribunais continuam a ter o poder de declarar incompatibilidade após sua promulgação. Assim, o Parlamento está sempre sujeito a enfrentar uma declaração desse tipo. Apenas a revogação de um direito específico da Convenção ou da LDH como um todo podem criar a imunidade. Dessa maneira, ele pode assegurar tanto que os custos políticos de uma anulação não sejam muito baixos, quanto que o debate legislativo seja informado pelo ponto de vista judicial.

Embora a LDH pareça, assim, quanto a esse importante aspecto, superior tanto à LDDNZ quanto ao modo como a anulação canadense tem funcionado na prática, é importante notar que ela contém uma regra padrão diferente para o exercício do poder do parlamento de ter a última palavra em resposta a uma decisão de um tribunal. Enquanto o uso da anulação (no Canadá) ou do poder de emendar uma lei por meio de direitos expressamente sobrepujantes (na Nova Zelândia) exigem ação afirmativa por parte do legislativo, segundo a LDH uma lei declarada incompatível com um direito da Convenção permanece válida a menos que emendada ou revogada pelo Parlamento. Ainda é, novamente, cedo demais para saber com certeza, mas isso pode significar que os custos políticos de uma anulação reativa não sejam tão altos quanto no Canadá ou na Nova Zelândia. Em caso positivo, isso, por sua vez, pode ocasionar ou uma segunda vantagem ou uma primeira desvantagem em comparação com as outras duas: debates e diálogos desejáveis sendo provocados com maior frequência, ou a utilização muito fácil da anulação passiva.

\section{CONCLUSÃO}

É lugar comum observar que houve um crescimento tremendo do constitucionalismo no mundo desde 1945. Embora verdadeira, essa afirmação geral corre o risco de deixar de distinguir entre dois avanços bem diferentes que ocorreram. $\mathrm{O}$ primeiro é uma mudança para o constitucionalismo em muitos países; o segundo, uma mudança de uma forma de constitucionalismo para outra em diversos outros países. Essa distinção é em grande parte negligenciada porque, até bem recentemente, esses dois tipos de mudança resultaram na adoção do modelo norte-americano de constitucionalismo e isso, por sua vez, fez aumentar uma tendência tacanha de ver este como o único modelo. 
Sem dúvida, dos dois avanços, a mudança para o constitucionalismo foi a mais significativa e comentada. Após 1945, ela abarcou aqueles países que haviam sofrido com o fascismo e com ditaduras militares nos anos do entreguerras, em especial a Alemanha, a Áustria, o Japão, a Itália, a Espanha e Portugal. E desde 1989, espalhou-se até os países da Europa central e oriental recém-liberados da ditadura comunista.

Embora, como discutido, todos esses países tenham adotado os elementos essenciais do modelo norte-americano de constitucionalismo, é um erro pensar que este seja o único modelo disponível. Assim como exemplificado pelo Reino Unido, o Canadá e a Nova Zelândia pré-declarações de direitos, bem como pela França do entreguerras e da Quarta República e as contemporâneas Holanda e Luxemburgo (e também a Dinamarca e a Noruega, na prática), a polarmente oposta supremacia legislativa plena é uma forma igualmente venerável que os sistemas jurídicos e políticos constitucionalistas podem tomar. Isso é válido até quando essa mesma forma jurídica seja aquela dentro da qual governos não constitucionalistas possam também funcionar, embora, com certeza - como a história de muitos países latino-americanos testemunha - a forma jurídica do modelo norte-americano também não constitui garantia da substância.

Dentre os países que aderiram previamente ao modelo de supremacia legislativa de constitucionalismo, alguns, como a Bélgica e a França, mudaram, a partir de 1945, para o polo oposto do modelo norte-americano. Além disso, aqueles países da Europa ocidental que passaram de ditaduras para o constitucionalismo também escolheram esse modelo, em vez de retornar a seus sistemas constitucionalistas gerais de supremacia legislativa pré-ditaduras. Mais recentemente, é claro, o Canadá, a Nova Zelândia e o Reino Unido trocaram esse modelo a fim de assegurar garantias jurídicas mais formais para os direitos individuais. Embora essa mudança crie expectativas e tenha a intenção de lograr consequências importantes no que diz respeito ao desenvolvimento da cultura de direitos, isso também representa uma mudança dentro dos sistemas jurídicos e políticos constitucionalistas, e não uma mudança para um sistema.

Assim como a França e a Bélgica, esses três países da Comunidade Britânica se afastaram, em graus diferentes, do modelo tradicional de supremacia legislativa constitucionalista; porém, diferentemente delas, não adotaram a alternativa do modelo norte-americano. Em vez disso, criaram um novo modelo. Sua novidade está em adicionar uma terceira forma híbrida aos dois modelos anteriores, uma forma que supera a exclusividade mútua entre eles. De modo mais importante, embora conceda aos tribunais o poder de aplicar direitos fundamentais, ele desvincula o controle de constitucionalidade da supremacia judicial ao dar poder aos parlamentos de terem a última palavra.

Esse novo modelo foi feito sob medida para permitir maior tutela jurídica aos direitos dentro de culturas políticas nas quais existe apego substancial à soberania parlamentar por esta ter proporcionado uma longa e amplamente bem-sucedida tradição de democracia constitucionalista. Porém, embora o ímpeto para o novo modelo tenha vindo do polo da supremacia legislativa dentro do espectro, ele aborda de maneiras novas interesses que têm suas raízes no pólo oposto. Como tal, merece observação e exame cuidadosos, tanto por aqueles que se converteram recentemente para o modelo norte-americano quanto para os seus membros fundadores. 


\title{
THE NEW COMMONWEALTH MODEL OF CONSTITUTIONALISM
}

\begin{abstract}
The "new Commonwealth model of constitutionalism" refers to a common general structure or approach underlying the bills of rights introduced in Canada (1982), New Zealand (1990), and the United Kingdom (1998). As a recent and ongoing experiment in constitutional design, the new Commonwealth model may be something new under the sun. It represents a third approach to structuring and institutionalising basic constitutional arrangements that occupies the intermediate ground in between the two traditional and previously mutually exclusive options of legislative and judicial supremacy. It also provides novel, and arguably more optimal, techniques for protecting rights within a democracy through a reallocation of powers between courts and legislatures that brings them into greater balance than under either of these two lopsided existing models. In this way, the new Commonwealth model promises to be to forms of constitutionalism what the mixed economy is to forms of economic organization: a distinct and appealing third way in between two purer but flawed extremes.
\end{abstract}

Keywords: Weak-form Judicial Review. Judicial Supremacy. Democratic Constitutionalism. Legislative Override. UK Human Rights Act.

\section{EL NUEVO MODELO DE CONSTITUCIONALISMO DE LA COMUNIDAD BRITÁNICA}

\section{RESUMEN}

El "nuevo modelo de constitucionalismo de la Comunidad Británica" se refiere a una estructura o abordaje general común subyacente a las cartas de derechos introducidas en Canadá (1982), Nueva Zelandia (1990) y Reino Unido (1998). Como un experimento reciente y continuo en diseño constitucional, el nuevo modelo de la Comunidad Británica puede ser algo inédito. El representa un tercer abordaje a la estructuración e institucionalización de disposiciones constitucionales básicas, que ocupa el punto intermediario entre las dos tradicionales opciones de supremacía legislativa y judicial, que se excluían mutuamente. El también provee técnicas nuevas y, se puede argüir, mejores para proteger derechos adentro de una democracia por medio del traslado de poderes entre cortes y legislaturas, lo que establece un más grande equilibrio que cualquiera de los dos modelos asimétricos. De esa manera, el nuevo modelo de la Comunidad Británica promete ser para los modelos de constitucionalismo lo que la economía mixta es para las formas de organización económica: una tercera vía distinta y atrayente, entre dos extremos más puros, pero defectuosos. 
Palabras-clave: Control Judicial Flaco de Constitucionalidad (Weak-form Judicial Review). Supremacía Judicial. Constitucionalismo Democrático. Anulación Legislativa. Ley de Derechos Humanos de Reino Unido.

1 A tradução do presente artigo foi gentilmente cedida pelo Prof. Dr. Luis Moreira, editor da coleção de títulos internacionais da Editora Del Rey (Belo Horizonte). O trabalho foi originalmente publicado na obra "Legitimidade da Jurisdição Constitucional", organizado por Antonio Carlos Alpino Bigonha e Luiz Moreira, com tradução de Adauto Villela. Para fins de republicação, a tradução foi revisada por Tércio Aragão Brilhante. A equipe editorial da Revista Opinião Jurídica optou por manter o formato original do artigo no que concerne ao seu sistema de referenciação.

2 Agradeço a Richard Buxbaum, Ken Karst, Grant Nelson, Michael Perry, Seana Shiffrin, David Sklansky, membros do Grupo de Discussão de Direito e Filosofia de Los Angeles, e aos alunos de meu seminário de direito constitucional comparado pelos comentários extremamente úteis a uma versão anterior deste trabalho.

3 Livros de direito constitucional comparado tendem a começar recontando esse avanço como o fornecedor da matéria-prima da disciplina. Veja Mauro Cappelletti e William Cohen, Direito constitucional comparado: casos e materiais (e 1979), Capítulo 1: "A história e a expansão contemporânea do judicial review" [Comparative Constitutional Law: Cases and Materials (1979), Chapter 1: "The History and Contemporary Expansion of Judicial Review"]; Vicki Jackson \& Mark Tushnet, Direito constitucional comparado [Comparative Constitutional Law] v-ix (1999). Veja também, Kommers, "O valor do direito constitucional comparado" ["The Value of Comparative Constitutional Law"], 9 John Marshall L. Rev. 685, 686 (1976) (citando o "sucesso relativo dos recém-criados tribunais constitucionais" " "o fenômeno do judicial review que se alastra em diversas partes do mundo" como causa do surgimento do direito constitucional comparado como disciplina ministrada nos Estados Unidos); Ackerman, "O surgimento do constitucionalismo mundial" ["The Rise of World Constitutionalism"], 83 Virginia L. Rev. 771 (1997) (argumentando que os acadêmicos norte-americanos do direito deveriam contribuir para a análise da "esperança de iluminação em constituições escritas" e dos tribunais constitucionais que estão atualmente surgindo pelo mundo).

4 Para uma breve discussão desses avanços, veja o item 2 infra.

5 Esses elementos essenciais foram arrolados pela primeira vez pelo Juiz Presidente John Marshall quando este buscava na Suprema Corte dos Estados Unidos um poder para invalidar legislação que conflitasse com a Constituição, embora tal poder não se encontrasse explícito no texto desta. Marshall apresentou esses argumentos no contexto geral do direito constitucional, mais do que no contexto específico dos direitos fundamentais, mas isso não altera o argumento, uma vez que esses direitos estão incluídos na Constituição. De acordo com Marshall: "Entre essas alternativas não existe meio termo. Ou a Constituição é uma lei superior e suprema, não sujeita a alteração pelos meios ordinários, ou se encontra no mesmo nível das leis ordinárias, e, como qualquer outra lei, pode ser alterada quando o legislativo bem entender". Visto ser a Constituição de fato lei suprema, os tribunais devem então ter o poder de invalidar leis conflitantes como parte de seu dever ordinário de decidir uma ação ou controvérsia à qual ambas, Constituição e leis, se apliquem. Marbury v. Madison, 1 Cranch (5 US) 137 (1803), p. 177.

6 Embora a supremacia legislativa e a proteção efetiva de direitos fundamentais sejam, assim, vistas como incompatíveis, no sentido de que a primeira expressa as reivindicações do majoritarismo ilimitado e a segunda, aquelas dos seus limites, elas não formam um sistema binário de tal modo que cada sistema jurídico deva adotar ou uma ou outra. Logo, diversos sistemas jurídicos, tanto do passado quanto do presente, impõem limites jurídicos ao poder legislativo sem proteger diretamente direitos fundamentais. O federalismo e a separação de poderes são os maiores exemplos. Anteriormente às suas ditaduras do entreguerras, a Alemanha e a Áustria instituíram uma forma de controle de constitucionalidade para impor limites de separação de poderes aos diversos poderes do governo. Esse era o projeto original do sistema francês na Quinta República, com o controle de constitucionalidade policiando as fronteiras entre o poder legislativo e o executivo, mais do que protegendo direitos fundamentais. A Austrália possui uma constituição com controle de constitucionalidade do federalismo, mas sem ter uma declaração de direitos. Essa foi, é claro, em certa medida, a forma original da Constituição dos Estados Unidos antes da adoção da Declaração de Direitos e Garantias em 1791 (embora haja uns poucos direitos no corpo do texto da Constituição) e antes da incorporação da Declaração de Direitos da Décima Quarta Emenda contra os estados no séc. XX. 
7 Por "coletivamente menos percebidos", eu quero dizer principalmente que existe pouca produção acadêmica dentro do direito constitucional comparado atentando para esses avanços como um todo. Há, é claro, uma grande quantidade de estudos, em cada um dos países desse grupo, acerca dos avanços avaliados individualmente, veja as obras citadas na Parte III infra. Dentro dos Estados Unidos, existe alguma discussão sobre os avanços no Canadá. Veja, por exemplo, Mary Ann Glendon, Conversa de direitos: o empobrecimento do discurso político [Rights Talk: The Impoverishment of Political Discourse] 39 (1991) (a Constituição canadense mostra como "os direitos podem aparecer de forma forte, mas não absoluta"); Michael J. Perry, A constituição nos tribunais: lei ou política? [The Constitution in the Courts: Law or Politics?] 196-201 (1994) (advogando que se leve em consideração nos Estados Unidos o mecanismo "anulatório" canadense); Tushnet, "Distorção política e debilitação democrática: esclarecimento comparado da dificuldade contramajoritária" ["Policy Distortion and :Democratic Debilitation: Comparative Illumination of the Countermajoritarian Difficulty"], 94 Mich. L. Rev. 245 (1995) (a experiência canadense indica que pode não haver alternativa real ao "minimalismo judicial" thayeriano como solução para o problema da debilitação democrática).

8 O termo foi cunhado por Alexander Bickel, O poder menos perigoso [The Least Dangerous Branch] p. 16 (1962). Para uma discussão dessa questão, veja Parte IV, C infra.

9 Bogdanor, "Devolução: os aspectos constitucionais" ["Devolution: The Constitutional Aspects"], in Reforma constitucional no Reino Unido: práticas e princípios [Constitutional Reform in the United Kingdom: Practices and Principles] (1998).

101998 Human Rights Act (c.42). Esta lei entrou em vigor em $1^{\circ}$ de outubro de 2000.

11 O Reino Unido tomou parte originalmente da Convenção Europeia dos Direitos Humanos, um tratado internacional concluído sob os auspícios do Conselho da Europa em 1950. A Convenção contém um conjunto de direitos e liberdades individuais que as partes se comprometeram a não violar e que é aplicado pelo Tribunal Europeu dos Direitos Humanos, com sede em Estrasburgo, na França. $\mathrm{O}$ tratado não exige que as partes incorporem os direitos como parte do direito nacional de cada um, embora a maioria o tenha feito, o que significa que os indivíduos desses países podem buscar amparo contra violações desses direitos nos tribunais nacionais sem iniciar uma ação no Tribunal de Estrasburgo. A LDH foi promulgada para incorporar a CEDH ao direito nacional do Reino Unido pela primeira vez.

12 Tushnet rotula esses dois problemas criados pelo judicial review de "debilitação democrática" e "deslocamento democrático" respectivamente. Veja Tushnet, n. 5 supra, pp. 246-47.

13 A Constituição dos Estados Unidos foi a primeira constituição escrita moderna e a primeira a ter um status efetivo de lei suprema. A explicação para as disposições da Constituição detalhada nos Jornais Federalistas destacam a originalidade da tentativa republicana de curar as doenças das antigas repúblicas e de proteger a liberdade através de mecanismos estruturais de freios e contrapesos. Veja também Gordon S. Wood, A revolução norte-americana: uma história [The American Revolution: A History] pp. 159-62 (2001) (descrevendo a manutenção pela Constituição da soberania no povo, em vez de simplesmente derivá-la dele e depositá-la em uma instituição do governo como "um dos momentos mais criativos na história do pensamento político").

14 A constituição britânica não é um documento único ou um grupo de documentos, mas, o conjunto global de leis (legisladas e consuetudinárias), regras, princípios, convenções e práticas que, coletivamente, definem a composição, as funções e os interrelacionamentos das instituições do governo e delineiam os direitos e as obrigações dos governados.

15 A definição clássica de soberania do Parlamento foi dada por Dicey: "O parlamento... tem o direito de fazer ou desfazer qualquer lei; e, ainda, o de que nenhuma pessoa ou órgão seja reconhecido pela lei da Inglaterra como detentor do direito de anular ou ab-rogar a legislação do Parlamento". A. V. Dicey, Introdução ao estudo do direito da Constituição [Introduction to the Study of the Law of the Constitution] 38 (8th ed., 1920). Dicey descreve a soberania do Parlamento como "a característica dominante de nossas instituições políticas, de um ponto de vista jurídico". Id., p. xviii.

16 Esses limites implicam que a uns poucos poderes legislativos sejam negados tanto aos governos estaduais quanto ao federal; assim, todos os poderes legislativos restantes estão divididos entre a nação e os Estados no sistema federalista, de acordo com a doutrina dos poderes enumerados. O poder legislativo federal é ainda limitado pela doutrina da separação dos poderes e, a partir de 1791, também pela Declaração de Direitos e Garantias. A Décima Quarta Emenda foi, em última instância, interpretada para incorporar quase todos os limites contidos na declaração de direitos contra os Estados. É claro, a própria Constituição não contém uma 
concessão clara do poder do judicial review aos tribunais, mas ele foi inferido pelo Juiz Presidente Marshall (e outros) a partir do status de lei suprema da Constituição, status este (com respeito à legislação federal) sendo uma inferência estrutural a partir de sua natureza escrita. Veja Marbury v. Madison, n. 3 supra.

17 Constituição dos Estados Unidos, Art. VI, Seção 2, tal como interpretada por Marbury, n. 3 supra, para conceder supremacia à Constituição sobre leis conflitantes do Congresso.

18 Veja Dicey, n. 13 supra.

19 O procedimento é o seguinte: o Congresso propõe emendas por maiorias de dois terços de ambas as casas, que devem ser ratificadas por três quartos dos legislativos estaduais (ou pelas convenções em três quartos nos Estados da forma como o Congresso determinar). Alternativamente, o Congresso deve convocar uma convenção constitucional para propor emendas quando dois terços dos legislativos estaduais assim requisitarem, ratificação pelos mesmos três quartos dos parlamentos estaduais (ou convenções estaduais). Constituição dos Estados Unidos, Artigo V. Os professores Bruce Ackerman e Akhil Amar argumentaram em separado que esse procedimento de maioria absoluta não é exaustivo, mas pode ser suplementado por procedimentos mais informais e de populistas. Veja Bruce Ackerman, Nós o povo: fundamentos [We the People: Foundations] (1991); Amar, O consentimento dos governados: emenda constitucional fora do artigo V ["The Consent of the Governed: Constitutional Amendment Outside Article V'] 94 Colum. L. Rev. 457 (1994).

20 Em Ellen Street Estates Ltd. v. Minister of Health, (1934) 1 KB 590, estava em questão uma lei de 1919 que continha uma disposição determinando que leis posteriores conflitantes "devem deixar de vigorar ou devem não ter efeito...”. Uma lei de 1925 entrou em conflito com a com a lei de 1919, mas o Tribunal de Recursos julgou que a lei de 1919 devia ceder àquela. "O parlamento não pode, de acordo com nossa constituição, vincular-se no que diz respeito à forma da legislação subsequente, e é impossível para o parlamento ordenar que, em uma lei subsequente que trate do mesmo objeto, não possa haver anulação tácita. Se, em uma lei posterior, o parlamento escolher deixar claro que uma lei anterior está sendo anulada até certo ponto, essa intenção deve vigorar apenas porque ela é a vontade do legislativo".

21 Alega-se às vezes que o Congresso tem o poder de responder limitando a jurisdição dos tribunais federais, inclusive a da Suprema Corte, por meio de maioria simples conforme o poder outorgado pelo Artigo III, Seção 2, Cláusula 2. O emprego desse poder ainda não capacitaria o Congresso a derrubar decisões individuais já transmitidas pelos tribunais (as quais, presumivelmente, reteriam seu valor de precedente), a não ser para impedir que categorias específicas de ações fossem admitidas no futuro. Mais importante ainda, "o poder de regular a jurisdição nunca serviu de limite significativo para o poder do judicial review", Tushnet, n. 5 supra, pp. 285-87. Para maiores informações sobre esse assunto, veja nn. 152-54 infra.

22 Estou apresentando aqui a concepção britânica tradicional de soberania parlamentar. Esta foi alterada quando o Reino Unido tornou-se membro da União Europeia (UE). De acordo com a lei da UE, esta tem supremacia sobre todas as leis nacionais e os juízes devem garantir essa supremacia fazendo vigorar aquela sempre que haja conflito. Os tribunais britânicos admitiram que essa exigência é derivada da participação na UE, e passou a ser aplicável no Reino Unido com a Lei das Comunidades Europeias [European Communities Act] de 1972. Desta maneira, outorga-se tacitamente este poder aos tribunais. Veja Regina v. Secretary of State for Transport ex parte Factortame Ltd. (1991) AER 70 ("De acordo com os termos da Lei das Comunidades Europeias de 1972, sempre esteve claro que era dever de um tribunal do Reino Unido... anular qualquer norma do direito nacional considerada conflitante com qualquer norma diretamente aplicável do direito comunitário da UE”). De modo semelhante, interpretou-se que aquela exigência de garantir supremacia à lei da UE invalidasse a teoria da revogação tácita, a qual também seria incompatível com o status supremo daquela. O parlamento continua a ter a liberdade de emendar ou revogar a Lei das Comunidades Européias e existem algumas indicações dos tribunais de que, caso o Parlamento chegue a declarar expressamente que tem a intenção de agir de forma incompatível com a lei da UE, os tribunais obedecerão ao Parlamento, embora isso pareça incongruente com a supremacia plena da lei da EU. Veja Macarthys Ltd. v. Smith (1979) 3 AER 325 ("se chegar a acontecer de nosso Parlamento aprovar deliberadamente uma lei com a intenção de repudiar o Tratado ou qualquer disposição deste ou, ainda, de agir intencionalmente de forma incompatível com ele e de afirmar que assim os fez em termos expressos, então eu entenderia que seria dever de nossos tribunais seguir a lei de nosso Parlamento"). A concepção tradicional também foi alterada pela LDH do modo discutido no item 3 infra.

23 O Artigo 6 da Declaração dos Direitos do Homem de 1789 declarou que as leis (lois) são a expressão suprema 
da vontade geral. Interpretou-se que isso significava que as promulgações do Parlamento gozavam de um status apropriado à expressão da vontade do soberano. Veja John Bell, Direito constitucional francês [French Constitutional Law] 25 (1992).

24 Fato de que a forma do poder legislativo legalmente ilimitado seja frequentemente o veículo para regimes ditatoriais e não-constitucionalistas não deveria levar a que se negasse erroneamente que essa é uma forma de constitucionalismo. Em muitos países da América Latina a forma do modelo norte-americano, adotada durante o séc. XIX, foi também veículo para ditaduras. Veja Allen Brewer-Carias, Controle de Constitucionalidade no direito comparado [Judicial Review in Comparative Law] 156 (1989). O que esses dois fatos deixam perceber é que o constitucionalismo não pode ser reduzido à forma.

No Canadá, na Austrália e na Alemanha, alguma forma de controle de constitucionalide judicial das fronteiras do federalismo entre os governos centrais e provinciais apareceram antes de 1945, mas não a respeito de direitos individuais.

25 Constituição irlandesa, Artigo 34, Seção 3, Cláusula 2: "Salvo se previsto de outra maneira neste Artigo, a jurisdição do Tribunal Superior deve estender-se à questão da validade de qualquer lei que se relacione com as disposições desta Constituição, e nenhuma questão desse tipo deve ser levantada... em qualquer tribunal... que não seja o Tribunal Superior ou a Suprema Corte".

26 A Constituição austríaca não continha declaração de direitos, principalmente devido ao ponto de vista de Hans Kelsen de que os direitos individuais ("normas de direito natural") eram inapropriados para o controle judicial. Ao discutir o trabalho do Tribunal Constitucional austríaco, Cappelletti e Cohen observaram que "as leis que cerceavam as liberdades individuais permaneceram, praticamente falando, fora do âmbito de controle do Tribunal". Cappelletti \& Cohen, n.1 supra, pp. 87.

27 Sobre a estrutura e a jurisdição desse tribunal, veja Brewer-Carias, n. 22 supra, pp. 225-26.

28 A decisão do Reichsgericht de 4 de novembro de 1925 afirmou o controle de constitucionalidade judicial de forma muito clara. Porém, como um comentador descreveu a situação, os tribunais alemães "não [utilizaram o poder] para proteger direitos fundamentais". Favoreu, "Controle de constitucionalidade na Europa" ["Constitutional Review in Europe"] in Constitucionalismo e direitos: a influência da Constituição dos Estados Unidos no exterior [Constitutionalism and Rights: The Influence of the United States Constitution Abroad] (Louis Henkin \& Albert Rosenthal eds., 1990). Veja também Brewer-Carias, n. 22 supra, p. 204 ("não obstante, a situação do sistema de controle de constitucionalidade [na Alemanha] até 1933 não era tão completamente clara, de modo que o controle de constitucionalidade de leis federais por todos os tribunais nem sempre foi aceita e era frequentemente criticada").

29 Na França, o Conselho Constitucional exercita o controle de constitucionalidade com respeito aos direitos individuais desde 1971 somente, quando interpretou que o preâmbulo da Constituição de 1959 incorporava tanto a Declaração dos Direitos do Homem de 1789 quanto os direitos contidos no preâmbulo da Constituição de 1946 da Quarta República. Decisão do CC no. 71-44 DC de 16 de julho de 1971. O Conselho, que é menos um tribunal do que um órgão independente nomeado pelas instituições políticas, exercita apenas um controle a priori. Isto é, ele pode revisar leis para determinar se há compatibilidade com a Constituição apenas antes que elas sejam oficialmente promulgadas pelo Presidente. Veja n. 43 infra.

30 O Artigo 120 da Constituição holandesa declara que: "A constitucionalidade das leis do Parlamento não deve ser revista pelos tribunais".

31 Veja Husa, "Constitucionalidade dos países nórdicos" ["Constitutionality in Nordic Countries"], 48 Am. J. of Comp. L. 345, 365 (2000): a Seção 106 da Lei Básica de 2000 "possibilita controle limitado da constitucionalidade das leis nos tribunais; rejeição para aplicar da disposição da lei (sic), onde a aplicação da provisão da lei resultaria em clara controvérsia com a Constituição em geral e com a Lei Básica em particular. O tribunal pode, assim, dar prioridade à regulamentação da Lei Básica". Esta é uma inovação da Finlândia e complementa o controle existente conduzido por um comitê legislativo antes da promulgação.

32 O controle de constitucionalidade judicial quase nunca foi utilizado. Sobre os quatro países nórdicos, veja id.

33 A Polônia foi o único país do antigo bloco soviético a possuir um tribunal constitucional, o qual foi instituído em 1986 com poderes muito limitados para tentar prevenir a oposição ao regime. Após a queda dos comunistas, os poderes referentes ao controle de constitucionalidade dos tribunais foram aumentados. Até 1997, o parlamento podia anular, com uma maioria de dois terços, uma decisão do tribunal que invalidasse uma lei, mas esse poder de anulação foi abolido na Constituição de 1997. 
34 Para uma análise de suas disposições, veja Henckaerts and van der Jenght, "Proteção dos direitos humanos conforme as novas constituições da Europa central" ["Human Rights Protection under the New Constitutions of Central Europe"], 20 Loyola Int. and Comp. L. J. 475 (1998); Ludwikowski, "Direitos constitucionais fundamentais nas novas constituições da Europa oriental e central" ["Fundamental Constitutional Rights in the New Constitutions of Eastern and Central Europe”], 3 Cardozo J. Int'l. \& Comp. L. 73 (1995).

35 Veja Alston, "Uma estrutura para a análise comparativa de declarações de direitos" ["A Framework for the Comparative Analysis of Bills of Rights"] in A promoção dos direitos humanos através das declarações de direitos: perspectivas comparadas [Promoting Human Rights Through Bills of Rights: Comparative Perspectives] 1-2 (Philip Alston ed., 1999).

36 Veja, e.g., DeShaney v. Wisconsin, Winnebago County Dep't of Social Services, 489 U.S. 189 (1989) para uma bem conhecida afirmação dessa posição pela Suprema Corte. Veja também Jackson v. City of Joliet, 715 F. 2d 1200, 1206 (7th Cir.) (1983) ("Nossa Constituição é uma Carta de liberdades negativas, mais do que de liberdades positivas... Os homens que redigiram a Declaração de Direitos e Garantias não estavam preocupados com a possibilidade de que o governo fizesse pouco pelo povo, mas que ele fizesse muito com o povo". Posner, J). Veja também, Currie, "Direitos constitucionais positivos e negativos" ["Positive and Negative Constitutional Rights"] 53 U. Chi. L. Rev. 864 (1986).

37 Dois exemplos são a Hungria, onde o Tribunal Constitucional declarou em diversas ocasióes que o Parlamento agiu inconstitucionalmente por omissão (veja "Refolução" ["Refolution"] 12 Am. U.J.Int'l L. \& Pol'y 87, 96 (1997), e a Alemanha. Em seu primeiro julgamento de aborto, o Tribunal Constitucional alemão decidiu que as disposições constitucionais protegendo a dignidade humana e o direito à vida exigiam que o parlamento criminalizasse o aborto (em seu segundo julgamento, o Tribunal julgou que o aborto não precisaria mais ser criminalizado, mas que deveria ainda ser considerado ilegal). Primeira Decisão Judicial sobre Aborto, 39 BVerfGE 1 (1975). De maneira semelhante, julgou-se que a garantia de liberdade de difusão televisiva que consta do Artigo 5(1) exigem que o Estado institua uma estrutura jurídica na qual todos os interesses significativos possam se fazer ouvir. Ação de Televisão 1, 12 BVerfGE 205 (1961).

38 Isso pode ser conseguido diretamente, com a criação de uma ação de responsabilidade civil constitucional, como na Irlanda (veja Hosford v. John Murphy Ė Sons (1987) I.R. 621) e na África do Sul, ou indiretamente, como na Alemanha, ao exigir-se que o direito privado seja interpretado à luz da Constituição (o assim chamado Drittwirkung, ou efeito recíproco, da Lei Básica sobre o direito civil).

39 Por exemplo, diferentemente da Constituição dos Estados Unidos, todas as três declarações de direitos examinadas neste artigo contêm, de modo expresso, limites permissíveis sobre esses direitos. Veja n. 136 infra.

40 Pois o primeiro tribunal constitucional da Europa, o austríaco, que permaneceu em atividade entre 1920 e 1933, era desse tipo.

41 Em grande parte, essa diferença depende de se concordar ou discordar com o argumento de Marshall de que o judicial review faz parte da função judicial decisória ordinária. Veja Marbury v. Madison, n. 3 supra. Caso se aceite essa caracterização, segue-se que, uma vez que todos os tribunais exercitam a função judicial ordinária, eles deveriam também ter o poder do judicial review. Os sistemas europeus tendem a ver o controle de constitucionalidade como uma função mais política e extraordinária, logo, menos apropriada aos tribunais comuns. Para outras razões jurídicas, institucionais e culturais que explicam a escolha do sistema centralizado na Europa, veja Cappelletti \& Cohen, n. 1 supra, pp. 73-83.

42 Veja id. pp. 84-95.

43 Por exemplo, Canadá, Alemanha, Itália Espanha e Portugal permitem tanto o controle abstrato quanto o concreto; a França permite somente o controle abstrato.

44 Por exemplo, na Alemanha o limite temporal para que instituições políticas busquem o controle abstrato de uma lei é de trinta dias. A Espanha mudou do controle a priori para o controle a posteriori em 1985.

45 Atualmente, a Áustria, França, Itália e Bélgica não permitem votos de dissentimento de seus tribunais constitucionais. A tendência permissiva é talvez explicável por uma percepção de que, à medida que a legitimidade geral dos tribunais cresce, as preocupações quanto à autoridade e a objetividade diminuem. Não se deve esquecer que o Juiz Presidente Marshall impôs uma pressuposição forte de unanimidade a seus colegas nos primórdios da Suprema Corte dos Estados Unidos.

46 Peter W. Hogg, Direito Constitucional do Canadá [Constitutional Law of Canada] 429, n. 74 (1977).

47 Declaração de Direitos e Garantias Canadense, S.C. 1960, c. 44, Seção 2. 
48 Id., Seção 1.

$49 R$ v. Drybones (1970) 3 C.C.C. 355 . Com uma maioria de cinco a quatro, o tribunal julgou que tinha poder para declarar "inoperante" uma lei que, na ausência de anulação parlamentar expressa, não podia ser interpretada de forma congruente com um direito protegido. A Seção 94 da Lei dos Índios de 1952, que tornava crime para os índios apresentarem-se embriagados fora da reserva, foi julgada inoperante por conflitar com uma disposição da DDGC contendo o direito de igualdade perante a lei, uma vez que não-índios não estavam sujeitos a proibição semelhante. Os quatro juízes que dissentiram argumentaram que, se a intenção do parlamento fosse a de conceder esse novo poder, ele o teria feito expressamente.

50 Veja, por exemplo, Tarnopolsky, "O contexto histórico e constitucional da Carta Canadense de Direitos e Liberdades proposta" ["The Historical and Constitutional Context of the Proposed Canadian Charter of Rights and Freedoms"], 44 Law $\mathcal{E}$ Contemp. Problems 169 (1981) (descrevendo fraquezas da DDGC).

51 O termo foi cunhado por Tarnopolsky, veja id. A redação da Seção 1 que deu origem a essa interpretação de "conceitos congelados" foi a seguinte: "Fica assim declarado que no Canadá existiam e continuarão a existir... os seguintes direitos humanos e liberdades fundamentais...". A redação "existiam" foi interpretada por esses juízes como significando que as leis existentes quando da declaração de direitos expressavam e determinavam o conteúdo dos direitos, querendo, assim, dizer que não poderiam estar violando quaisquer dos direitos.

52 Veja parecer de dissentimento de Pigeon, J em Drybones.

53 A DDGC, contudo, permanece em vigor e não foi revogada pela Carta.

54 Carta, Seção 15: "Todo indivíduo é igual perante a lei e tem direito à proteção igualitária e ao benefício da lei sem discriminação e, especialmente, sem discriminação baseada em raça, nacionalidade ou etnia, cor, religião, sexo, idade ou a incapacidade física ou mental".

55 Esta declarava que "Nenhuma lei do Parlamento do Reino Unido aprovada após a entrada em vigor da Lei da Constituição de 1982 estender-se-á ao Canadá como parte de seu direito". Lei do Canadá, 1982, Seção 2.

56 Veja, por exemplo, Weiler, "Direitos e juízes em uma democracia: a nova versão canadense" ["Rights and Judges in a Democracy: A New Canadian Version"], 18 U. Mich. J. L. Ref. 51 (1984), pp. 64-65. Embora a Suprema Corte canadense tenha julgado, em um parecer consultivo pleiteado por Trudeau em meio à crise constitucional, que, legalmente, o consentimento das províncias não era necessário para que o governo federal prosseguisse com o projeto de nacionalização (da Lei da América do Norte Britânica, em inglês: patriation), ela também declarou a que a convenção constitucional exigia tal acordo, mas sem especificar quantas províncias deveriam concordar. No final, Quebec foi a única província a não consentir com a solução conciliatória. Sobre o processo de Referência de Nacionalização [Patriation Reference case], veja Edward McWhinney, Canadá e a Constituição, 1979-1982: nacionalização e a Carta de Direitos [Canada and the Constitution, 1979-1982: Patriation and the Charter of Rights] 80-89 (1982).

57 Para o texto e a discussão da Seção 33, veja n. 61 infra.

58 O fato que os líderes políticos viam a Seção 33 como uma solução conciliatória dessa natureza não quer dizer que não existissem aqueles que a entendiam, de modo independente e intrinsecamente justificado, como estruturadora do sistema ótimo de proteção de direitos para o Canadá, tanto à época quanto posteriormente. Paul Weiler foi um dos arquitetos acadêmicos da Seção 33. Veja Weiler, "Dos juízes e dos direitos, ou, deveria o Canadá ter uma Declaração de Direitos constitucional?" ["Of Judges and Rights, Or Should Canada Have a Constitutional Bill of Rights?"], 1980 Dalhousie Rev. 205 (propondo a anulação legislativa de direitos constitucionais como a solução distintivamente canadense para o problema dos juízes e dos direitos em uma democracia). Veja também, Brian Slattery, Uma teoria da Carta [A Theory of the Charter] (1987); Weinrib, "Convivendo com a anulação" ["Living with the Override"] 35 McGill L. J. 541 (1990). Veja Weiler, n. 55 supra, n. 97.

59 Veja Weiler, n.55 supra, p. 97.

60 O procedimento geral de emenda está contido na Seção 38 (1): "Uma emenda à Constituição do Canadá deve ser feita por proclamação emitida pelo Governador Geral conforme autorização máxima do Canadá concedida através de (a) resoluções do Senado e da Câmara dos Deputados e (b) resoluções das Assembleias Legislativas de pelo menos dois terços das províncias que tenham, em conjunto e de acordo como o mais recente recenseamento geral, ao menos $50 \%$ da população de todas as províncias".

61 Assim como o citado acima, a Seção 52 declara que "qualquer lei que apresente incongruências com as disposições da Constituição não tem, quanto a tais incongruências, qualquer efeito". A Seção 24(1) da Carta 
declara que: "Qualquer indivíduo cujos direitos e liberdades, tal como garantidos por esta Carta, tenham sido infringidos ou negados pode recorrer a um tribunal de jurisdição competente para obter o remédio que o tribunal considere apropriado e justo conforme as circunstâncias".

62 Veja Bayard W. Reesor, A Constituição canadense em perspectiva histórica [The Canadian Constitution in Historical Perspective] 403 (1992).

63 A Seção 33 também permite anulações preventivas; isto é, a imunização de disposições legislativas contra o judicial review de acordo com a Carta. Veja n. $72-73$ infra.

64 Seção 33(3): Uma declaração feita de acordo com a subseção (1) deixará de ter efeitos cinco anos após sua entrada em vigor ou em data anterior que possa ser especificada na declaração. Seção 33(4): O Parlamento ou um legislativo de uma província pode promulgar novamente uma declaração feita em conformidade com a subseção (1).

65 Veja Weiler, n. 57 supra, pp. 46-47; veja também Weinrib, Slattery, n. 57 supra.

66 Veja Weiler, n. 55 supra, pp. 81-82: "Em uma sociedade suficientemente enamorada pelos direitos fundamentais ao ponto de consagrá-los em sua constituição, a evocação da expressão non obstante (não obstante) é garantia de oposição política ferrenha".

67 Para explicações mais detalhadas de como as coisas aconteceram, veja Weinrib, n. 57 supra; Tushnet, n. 5 supra, pp. 287-92.

68 Veja n. 55 supra.

69 Lei respeitando da Lei da Constituição de 1982, S.Q. 1982, c.21.

70 Veja Weinrib, n. 57 supra, n. 7.

71 A Carta entrou em vigor em 17 de abril de 1982 e o projeto de Québec foi promulgado em 23 de junho de 1982. A anulação foi para retroativa a 17 de abril.

72 Ford v. Québec, (1988) 2 S.C.R. 712, 54 D.L.R. (4th) 577. Houve duas objeções ao argumento de que a utilização pelo Quebec da anulação padrão violava o requisito de especificidade. Primeira, apenas uma disposição da Carta pode ser anulada por lei ("não obstante uma disposição... desta Carta") (ênfase adicionada). Segunda, a anulação deve especificar em palavras qual o direito da Carta está sendo anulado, a simples referência aos números de seções da Carta é insuficiente ("a lei... aplicará não obstante uma disposição incluída nas Seção 2 ou nas Seções 7 a 15 desta Carta") (ênfase adicionada). Palavras, não números, são necessárias para deixar mais claro para os eleitores o que o legislativo está propondo. $\mathrm{O}$ argumento textual contra a utilização omnibus da anulação vai no sentido de que a cláusula afirma que o legislativo pode declarar "em uma lei... que $a$ lei... vigorará não obstante..." (ênfase adicionada). O tribunal, em Ford, rejeitou todos os três argumentos.

73 A Corte julgou que "A Seção 33 estabelece requisitos de forma apenas, e não há autorização para que se importe para ela fundamentação para o controle substantivo da política legislativa ao se exercer a autoridade de anulação em um processo específico". Ford, p. 740-741. O requisito formal é o de uma declaração expressa apenas, e mesmo o uso de números ao invés de palavras e a utilização omnibus da anulação estavam suficientemente expressos. Um controle de constitucionalidade mais substancial do que esse exigiria que a Corte ultrapassasse a forma e revisasse a justificativa para o seu uso. Para uma crítica poderosa da decisão, veja Weinrib, supra n. 57, pp. 553-59.

74 O argumento textual a favor do uso da anulação apenas em resposta a uma decisão de inconstitucionalidade do tribunal, e não preventivamente, é o de que, se assim não for, a disposição legislativa não vigora "não obstante" outras disposições da Carta. Na ausência de uma declaração a priori de inconstitucionalidade, presume-se que o parlamento suponha que suas leis sejam congruentes com a Carta. Veja Tushnet, n. 5 supra, pp. 279-80 (citando Perry, n. 5 supra, pp. 199-201, Slattery, n. 57 supra, pp. 742; Weiler, n. 55 supra, pp. 90, n. 114).

Ao julgar válido o uso preventivo da anulação, o tribunal de Ford não proibiu o uso em resposta a uma decisão do tribunal, embora haja indicações de que o impedimento ao efeito retroativo de uma anulação impossibilita de forma significativa que os legislativos revertam decisões judiciais adversas. Veja Butler, "O debate sobre a Declaração de Direitos: por que a Lei da Declaração de Direitos da Nova Zelândia de 1990 é um mau modelo para a Grã-Bretanha?" ["The Bill of Rights Debate: Why the New Zealand Bill of Rights Act 1990 is a Bad Model for Britain”] 17 Ox J. Leg. St. 323 (1997). A utilização posterior da anulação, contudo, pareceria assegurar que uma lei invalidada possa ser aplicada a partir da data da anulação não obstante a decisão judicial. Apenas a reforma de um resultado individual de um processo parece ter sido rejeitada. 
75 Veja Tushnet, n. 5 supra, n. 203, fazendo menção a uma conversa na qual Bruce Ackerman chamou a atenção para esse fato. Veja também Weinrib, n. 57 supra, p. 557 (sugerindo que o tribunal de Ford entendeu mal o sistema alterado que foi introduzido pela Carta).

76 Veja Andrew Heard, Convenções constitucionais canadenses: o casamento da lei com política [Canadian Constitutional Conventions: The Marriage of Law and Politics] 147 (1991). Essas convenções parecem ter surgido, em parte, também como resultado da resposta do Quebec para aquela parte da decisão em Ford que invalidou a lei relativa ao uso exclusivo da língua francesa em letreiros, por violar a Seção 3 da própria Carta de Direitos do Quebec. Após Ford, o Quebec renovou a anulação de sua Carta, a qual expiraria em alguns meses. Heard, entre outros, atribui o colapso do Acordo de Meech Lake reconhecendo o status de "sociedade separada" do Quebec a essa renovação da anulação.

77 Saskatchewan v. Retail, Wholesale EO Dep't Store Union, [1987] 1 S.C.R. 460 (Can). O projeto de lei 144 de Saskatchewan, de janeiro de 1986, que forçava o sindicato a voltar ao trabalho e ditava os termos do novo acordo coletivo, continha uma cláusula isentando-o da Carta. Isso foi considerado necessário em virtude de uma decisão do Tribunal de Recursos de Saskatchewan de 1984 que revogava legislação similar com o fundamento de que ela infringia a liberdade de associação tal como garantida na Carta. Veja Lesson, "Seção 33, a cláusula não obstante: um tigre de papel" ["Section 33, the Notwithstanding Clause: A Paper Tiger"] 6 Choices IRPP 3 -20 (2000).

78 É claro, mesmo com Ford, é possível que os parlamentos adotem a norma de que a anulação deveria ser usada apenas em resposta a decisões da Suprema Corte. Veja, por exemplo, o Editorial, na Crim. L. Q. 42, 1 (1999), advogando essa posição. A norma existente, contudo, parece ter uso apenas ocasional e preventivo no Québec e estar em completo desuso em todos os outros lugares. Peter Hogg argumentou que, mesmo com a convenção contra o uso da anulação, o regime da nova Carta, na verdade, inaugurou o tão esperado diálogo entre os tribunais e os parlamentos, no sentido de que a maioria das leis revogadas pelos tribunais foram novamente promulgadas pelos legislativos com as devidas modificações. Hogg, A revolução da Carta: ela é não-democrática? ["The Charter Revolution: is it Undemocratic?"] Conferência de McDonald sobre Estudos Constitucionais [The McDonald Lecture in Constitutional Studies], proferida na Universidade de Alberta em 22 de março de 2001 (cópia arquivada na Revista Norte-Americana de Direito Comparado [Am. J. Comp. L.]). Essa é uma observação interessante e, de fato, reflete uma diferença em relação à prática estadunidense; mas eu não acredito que esse seja exatamente o diálogo que os proponentes do novo modelo tinham em mente.

79 Para detalhes dessa história, veja Rishworth, O nascimento e o renascimento da Declaração de direitos ["The Birth and Rebirth of the Bill of Rights"] in Grant Huscroft \& Paul Rishworth, Direitos e liberdades na Lei da Declaração de Direitos da Nova Zelândia de 1990 e o Direito Humano [Rights and Freedoms in the New Zealand Bill of Rights Act 1990 and the Human Right] (1995); Geoffrey Palmer, A Constituição da Nova Zelândia em crise: reformulando nosso sistema político [New Zealand's Constitution in Crisis: Reforming Our Political System] (1993); Joseph, "A Declaração de Direitos da Nova Zelândia” ["The New Zealand Bill of Rihts”], 7 Pub. L. Rev. 162 (1996).

80 "Nenhum tribunal deverá, em relação a qualquer lei (tenha sido esta aprovada ou promulgadas antes ou após a entrada em vigor da Declaração de Direitos): (a) julgar qualquer disposição da lei como tacitamente anulada ou revogada, ou de alguma forma inválida ou ineficaz ou (b) negar-se a aplicar qualquer disposição dessa lei com o único fundamento de que a disposição é incompatível com qualquer disposição desta Declaração de Direitos”. Lei de Declaração de Direitos da Nova Zelândia de 1990, Seção 4.

81 Obviamente, esse custo político é imposto ao legislativo apenas a respeito de leis incompatíveis promulgadas após a LDDNZ, não antes, mesmo que o dever jurídico dos tribunais se aplique a ambas.

82 A congruência entre as Seções 4 e 6, bem como a prioridade relativa entre elas, tem sido uma fonte constante de confusão da Nova Zelândia. Isso faz parte do assim chamado "problema 4-5-6", veja n. 87 infra.

83 Veja nn. 47-52 supra.

84 Este é menos controverso no sentido de que a teoria da anulação tácita, de acordo com a qual uma lei anterior é tacitamente anulada por uma posterior naquilo em que conflitem, é uma característica típica da soberania do parlamento nos sistemas jurídicos da Comunidade Britânica. Algumas opiniões não vinculantes dos juízes em Drybones, e em alguns outros processos posteriores, indicavam que o poder de invalidação se estendia também a leis incompatíveis subsequentes.

85 De fato, esse foi o fundamento lógico da maioria em Drybones, veja n. 48 supra, se bem que no contexto de uma lei anterior. A redação da disposição anulatória expressava a intenção do parlamento de que, ausente uma declaração desse tipo, o direito deveria prevalecer. 
86 Embora a Suprema Corte canadense não tenha tomado isso de forma literal. A decisão majoritária em Drybones tinha como premissa a incompatibilidade da Seção 94 da Lei dos Índios de 1952 com a garantia de igualdade perante a lei da DDGC.

87 Veja Rishworth \& Joseph, n. 78 supra. Veja também Taggart, "Puxando a capa do super-homem" ["Tugging on Superman's Cape"] in Constitutional Reform in the United Kingdom: Practice and Principles (cf. n. 7 supra) 85-97 (1998).

88 O problema é saber qual sequência ou metodologia um tribunal deveria usar ao decidir ações em conformidade com a LDDNZ, dadas as aparentes incongruências entre a Seção 4 (os tribunais não têm poder para invalidar leis conflitantes e expulsar a regra da anulação tácita), a Seção 5 ("limitações justificadas aos direitos") e a Seção 6 (dever interpretativo dos tribunais).

89 Veja e.g., Butler, n. 73 supra (argumentando, inter alia, que a escolha judicial quanto a dar prioridade à Seção 4 ou à Seção 6 é, efetivamente, uma escolha subjetiva, levando a significativa incerteza jurídica).

90 Veja R v. Butcher (1992) NZLR 257, 264 -65 (Cooke P) e 269 (Gault J); R v. Te Kira (1993) 3 NZLR 257, 261 (Cooke P) e 277 (Thomas J). Este último ponto se opõe diretamente aos argumentos apresentados por alguns juízes canadenses. Veja o parecer de dissentimento de Pigeon, J em Drybones ("Eu também não consegui ver como se pode dizer que ler a Seção 2 como pouco mais do que uma regra de interpretação é deixar de dar efeito à Declaração. Com base em quê se presume que qualquer outra coisa foi em intencionada em uma lei que não têm caráter constitucional?"). Id. pp. 40-41.

91 Este é o termo usado pelos comentadores da Nova Zelândia, veja n. 78 supra.

92 R v. Kirifi (1992) 2 NZLR 8.

93 Simpson v. Attorney-General (o caso de Baigent), (1994) 3 NZLR 667.

94 Ministry of Transport v. Noort (1992) 3 NZLR 260, 272 (Cooke P).

95 A mudança na cultura neozelandesa em direção à jurisprudência centrada em direitos é um tema comum de muitas reflexões acadêmicas sobre o efeito da LDDNZ. Veja, por exemplo, Taggart, n. 86 supra, p. 97; Joseph, n. 78 supra, pp. 168-69.

96 "Sempre que um projeto de lei por apresentado à Câmara dos Deputados, o Procurador Geral deve: (a) no caso de um projeto de lei do governo, quando da apresentação desse projeto ou (b) em qualquer outro caso, tão logo seja praticável após a apresentação do projeto, chamar a atenção da Câmara dos Deputados para quaisquer disposições do projeto que pareçam ser incompatíveis com quaisquer dos direitos e liberdades desta Declaração de Direitos". Lei da Declaração de Direitos, Seção 7.

97 Tal dever foi imposto ao Ministro da Justiça a respeito de leis federais de acordo com a Seção 3 da Declaração de Direitos canadense, de 1960.

98 Embora no contexto da Nova Zelândia, argumentou-se que uma decisão parlamentar de promulgar uma lei ante uma opinião do Procurador Geral de que ela viola direitos não significa necessariamente que o parlamento manifestou intenção de violar um direito. Alguns membros do parlamento poderiam discordar da opinião do Procurador Geral de que existe um conflito.Veja Butler, n. 73 supra, pp. 336-37.

99 As outras eram a devolução de poder para a Escócia e o País de Gales, a reforma da Câmara dos Lordes, um prefeito eleito e uma nova autoridade para Londres, liberdade de informação e um plebiscito quanto ao sistema eleitoral para as eleições gerais.

100 Lester, "O impacto da Lei de Direitos Humanos sobre o direito público" ["The Impact of the Human Rights Act on Public Law"], in Reforma constitucional no Reino Unido [Constitutional Reform in the United Kingdom], n. 7 supra, p. 105.

101 O debate moderno começou com um panfleto de 1968 escrito por Anthony Lester, um proeminente jurista. Outros que advogaram a favor de uma declaração de direitos petrificada incluem Michael Zander, Uma declaração de direitos e garantias [A Bill of Rights] (3rd. ed. 1985); Ronald Dworkin, Uma declaração de direitos e garantias para a Grã-Bretanha [A Bill of Rights for Britain] (1990), e Lorde Scarman, um proeminente juiz que proferiu um discurso que recebeu grande publicidade em suas conferências de Hamlyn, dezembro de 1974.

102 Mais uma vez, esta última sustenta que o Parlamento pode fazer ou desfazer qualquer lei acerca de qualquer assunto e que nenhum tribunal é competente para questionar a validade de uma lei devidamente promulgada. Veja n. 13 supra.

103 Esse é o termo que a LDH utiliza para definir aqueles direitos da CEDH que foram incorporados. Estão excluídos o Artigo 1 ("As partes contratantes devem assegurar a todos em suas jurisdições os direitos e liberdades definidos na Seção I desta Convenção.") e o Artigo 13 ("Todos cujos direitos e liberdades previstos nesta 
convenção sejam violados deverão contar com um remédio jurídico eficaz perante uma autoridade nacional não obstante ter a violação sido cometida por pessoas atuando na qualidade de funcionário público.”).

104 "Legislação delegada" é o termo genérico na Grã-Bretanha para a legislação proveniente de delegação pelo Parlamento de seus poderes legislativos ao poder executivo. É chamada algumas vezes de legislação "subordinada" ou "secundária" e a maioria dela se dá na forma de instrumentos jurídicos. Veja Stanley de Smith \& Rodney Brazier, Direito constitucional e administrativo [Constitutional and Administrative Law] 334-38 (8th ed., 1998).

105 Os procedimentos detalhados para uma ordem de reparação são extremamente complexos. Veja a Seção 10 e o Anexo 2. Eles também estavam entre os aspectos mais controversos do projeto e o governo foi forçado a emendar seu esquema original, que permitia menor supervisão parlamentar de ordens de reparação.

106 Essa redação foi retirada do livro Branco do governo de 24 de outubro de 1997. Seção 2.10. No debate parlamentar, os ministros do governo reconheceram que apenas a respeito de questões de princípio altamente controversas, tal como aborto, poder-se-ia prever que a legislação não seria emendada ou anulada em resposta a uma declaração de incompatibilidade de um tribunal. Veja Hansard para o debate de 21 de outubro envolvendo Jack Straw, Secretário do Ministério do Interior: "Na esmagadora maioria dos casos, independente de qual partido estivesse no governo, eu acho que os ministros examinariam o assunto e diriam: 'foi emitida uma declaração de incompatibilidade e nós teremos que a aceitar. Teremos que remediar a deficiência encontrada na lei pelo Comitê Judicial da Câmara dos Lordes'... Embora eu espere que isso não ocorra, é possível conceber que em algum momento no futuro um Comitê Judicial da Câmara dos Lordes, composto de forma particular, chegue à conclusão de que a disposição relativa ao aborto... no Reino Unido... é incompatível com um artigo qualquer da Convenção... Meu palpite - este pode ser mais do que um palpite - é que qualquer partido que estivesse no poder teria que se desculpar e dizer que não aceitava nem aceitaria aquilo e que continuaria com a legislação existente sobre aborto".

107 Este é o termo que o preâmbulo da LDH utiliza para descrever o modo de incorporação empregado pelo direito interno do Reino Unido: "Uma lei para dar mais vigor aos direitos e liberdades garantidos pela Convenção Européia dos Direitos Humanos". A palavra "incorporação" não é utilizada. De fato, no debate parlamentar, Lorde Irvine, o Lorde Juiz Presidente, argumentou que a LDH deu "maior vigor" à CEDH sem a "incorporar" ao direito do Reino Unido. O Livro Branco do governo, contudo, referiu-se ao manifesto de compromisso do governo como tendo introduzido "legislação para incorporar a Convenção Européia dos Direitos Humanos ao direito do Reino Unido". Livro Branco: introdução e sumário.

108 Houve, é claro, uma grande quantidade de comentários acadêmicos na Grã-Bretanha sobre todos os aspectos da LDH. Entre os mais incisivos estão Ewing, A Lei dos Direitos Humanos e a democracia parlamentar ["The Human Rights Act and Parliamentary Democracy"] 62 Modern L. Rev. 79 (1999); Feldman, A Lei dos Direitos Humanos de 1998 e os princípios constitucionais ["The Human Rights Act 1998 and Constitutional Principles"] 19 Legal Stud. 165 (1999); Wade, A Declaração de Direitos do Reino Unido ["The United Kingdom's Bill of Rights"], in Constitutional Reform in the United Kingdom: Practice and Principles (cf. n. 7 supra) 61-68 (1998); Marshall, Nacionalizando direitos com reservas: a Declaração de Direitos Humanos de 1998 ["Patriating Rights — With Reservations: The Human Rights Bill 1998,"] id., pp. 73-84.

109 A implicação textual clara da LDH foi explicitada pelo Procurador-Geral em debate na Câmara dos Lordes. Veja Lords Hansard, 18 de novembro de 1997, coluna 522: "O esquema desta Declaração é este: caso leis sejam julgadas incompatíveis com fundamento na Convenção, então cabe ao Parlamento remediar isso. Nós não desejamos incorporar os direitos da Convenção e, depois, confiando em uma teoria da anulação tácita, permitir que os tribunais derrubem leis do Parlamento".

110 Veja por exemplo, Patrick Atiyah e Robert Summers, Forma e substância no direito anglo-americano [Form and Substance in Anglo-American Law] 100-12 (1987) (argumentando que "juízes ingleses em geral enfatizam a primazia global do significado comum das palavras utilizadas na lei, muito mais do que os juízes norte-americanos" e caracterizando a posição inglesa geral como sendo a de que o propósito legal deveria ser considerado apenas quando o texto legal não for claro). A despeito de algumas declarações judiciais e outras em sentido contrário e do uso limitado mais recente de declarações ministeriais como ferramentas interpretativas (Pepper v. Hart, (1993) AC 593), esta é ainda uma posição geral.

111 Veja a doutrina da anulação tácita, n. 18 supra.

112 "Os direitos da convenção não... tornar-se-ão parte de nosso direito nacional e não suplantarão, portanto, a legislação existente ou serão suplantados por legislação futura." Lorde Hansard, veja n. 106 supra, Coluna 
522 (ênfase adicionada).

113 Saber se os tribunais aderirão às intenções do governo é uma outra questão, pois existe precedente de longa data no sentido de que falta ao parlamento o poder para excluir a anulação tácita de suas leis. Veja Ellen Street Estates Ltd. v. Minister of Health, n. 18 supra. Tal exclusão da teoria da anulação tácita não seria, contudo, inteiramente sem precedentes, pois os tribunais reconheceram isso no contexto do direito da União Europeia. Eles interpretaram que a Lei das Comunidades Européias (LCE) de 1972, através da qual a lei da UE foi incorporada ao direito nacional do Reino Unido, excluía a anulação tácita de leis subsequentes em conflito com uma disposição da lei da UE. Apenas a intenção expressa de legislar de forma incompatível com a lei da UE e/ou de emendar ou anular a LCE seria eficaz. Veja n. 20 supra.

114 Livro Branco, Seção 2.16.

115 Como observei acima, isso é incompatível com a concepção tradicional britânica de soberania parlamentar e apenas foi aplicado previamente em relação ao direito da União Europeia, embora, nesse caso, a exclusão da regra da anulação tácita tenha sido realizada pelo judiciário em obediência ao Tribunal de Justiça Europeu. Veja n. 20 supra.

116 Uma versão da anulação legislativa canadense (com maioria necessária de dois terços) foi adotada brevemente na Polônia entre 1986 e 1997, veja n. 31 supra. Ela também foi adotada recentemente em Israel a respeito da Lei Básica, a Liberdade de Ocupação Revisada, uma lei com status constitucional. A Seção 8 permite a anulação legislativa de direitos protegidos por maioria absoluta dos membros do Knesset, o Parlamento israelense, por um período máximo de quatro anos sem qualquer disposição para renovação. Esse poder também foi utilizado uma vez, logo após sua promulgação, na Lei de Importação de Carne Congelada, de 1994, a qual proibia a importação de carne e não kosher.

117 É importante observar novamente, contudo, que no contexto do direito da União Européia, os tribunais britânicos têm o poder do controle de constitucionalidade e afirmou-se que este é congruente com a soberania parlamentar desde que o Parlamento permaneça livre para emendar ou anular expressamente a Lei das Comunidades Europeias, de 1973, a qual torna a lei da UE parte do direito nacional do Reino Unido. Veja n. 20 supra. (Uma diferença, contudo, é que os tribunais, em vez do Parlamento, deram a si esse poder, interpretando-o como parte do pacote total de lei da UE incorporado pela LCE). Essa é uma segunda maneira possível pela qual o governo está errado ao sugerir que tenha protegido os direitos da convenção o máximo possível de forma compatível com as leis parlamentares (a primeira maneira foi expulsar a anulação tácita de leis anteriores). Isso seria ainda ligeiramente diferente do Canadá, no sentido de que a anulação não emenda ou anula a Carta, mas adia os efeitos sobre leis específicas por cinco anos - talvez um passo mais fácil de ser dado por um parlamento.

118 Veja o Livro Branco, Seção 2.13 ("Não existe qualquer evidência a sugerir que eles [os tribunais] desejam esse poder [o controle de constitucionalidade], nem de que o público quer que eles o tenham. Certamente, este governo não tem mandato para uma mudança dessas.").

119 Veja n. 20 supra.

120 A possibilidade de separação analítica dessas duas funções foi algumas vezes reconhecida no contexto das críticas direcionadas ao voto do Juiz Presidente Marshall em Marbury v. Madison. Ele é acusado - e em algumas ocasiões louvado - por tratar das questões mais fáceis, como saber (1) se uma lei incompatível com a Constituição pode constituir direito nacional e (2) se um tribunal, diante de uma lei como essa, está fadado a aplicá-la, mas de fugir da questão mais difícil de saber (3) quem decide se uma lei é incompatível. Embora essa crítica tenha a intenção de indicar que um tribunal pode ter o poder do controle de constitucionalidade sem possuir o poder independente de decidir se existe um conflito, pelo menos analiticamente, o oposto também deveria ser verdade, e agora a Grã-Bretanha acaba de fazer isso.

121 Veja n. 108 supra.

122 Veja n. 109 supra.

123 Jeremy Waldron, Direito e discordância [Law and Disagreement] 255-62 (1999).

124 O argumento clássico é de James Bradley Thayer em John Marshall (1901). Thayer considerava que a tendência dos legislativos, no contexto do judicial review agressivo, de deixar a consideração dos limites constitucionais para os tribunais e de presumir que eles fariam tudo o que pudessem fazer constitucionalmente, significava que "honra, negociação justa e honestidade não eram relevantes para suas inquirições". Além disso, uma vez que o judicial review envolvia a pressuposição de que erros legislativos deveriam ser corrigidos de fora para 
dentro, o resultado era que o povo perdia a "experiência política, a educação moral e o estímulo advindos... da correção dos próprios erros. A tendência de se recorrer normal e facilmente a essa grande função é diminuir o desenvolvimento da capacidade política do povo e de enfraquecer seu senso de responsabilidade moral".

125 Os exemplos mais bem conhecidos desse triunfo são a derrota infringida pelo Parlamento às reivindicações do monarca de governar por direito divino na Guerra Civil Inglesa e a Revolução Francesa.

126 Veja, por exemplo, James Madison, em The Federalist 48 ("Mas, em uma república representativa na qual a magistratura do executivo é cuidadosamente limitada... e na qual o poder legislativo é exercido por uma assembléia, a qual é inspirada por uma suposta influência sobre o povo com intrépida confiança em sua própria força, que é suficientemente numerosa para sentir todas as paixões que movem uma multidão, porém não tão numerosa a ponto de ser incapaz de perseguir os objetos de suas paixões pelos meios que a razão prescreve, vai contra a arrojada ambição deste poder a ideia de que o povo deva tolerar todo seu ciúme e exaurir todas as suas preocupações.").

127 Gordon Wood argumenta que a característica distintiva e mais radicalmente criativa da Constituição era precisamente sua recusa de institucionalizar a soberania popular em qualquer órgão político. Veja n. 11 supra.

128 Essa é a maneira como os acadêmicos da área jurídica descrevem o desenvolvimento da LDDNZ: uma declaração de direitos que se encaixa no paradigma da supremacia parlamentar, mas que, diferentemente da Declaração de Direitos canadense, de 1960, não se mostra insignificante por essa razão. Veja Rishworth, n. 78 supra, pp. 4. Mas penso que essa noção capta de forma útil a essência de todas as três Declarações de Direitos aqui examinadas.

129 Feita no contexto de normas constitucionais em geral, mais do que no daquelas que protegem especificamente direitos fundamentais. Veja n. 3 supra.

130 Lei da Constituição, 1981, Seção 38 (1).

131 Veja nn. 87-89 infra.

132 Veja Thayer, n. 122 supra.

133 O problema inverso também foi observado e chamado de "judicialização da política". Isso quer dizer que, com o controle de constitucionalidade em seu lugar, os parlamentos se tornam excessivamente preocupados com a questão da constitucionalidade e com o que os tribunais julgariam, com a tendência a acreditar que o que quer que seja constitucional constitui boa política. Veja Alec Stone, A judicialização da política na França [The Juridicaliztion of Politics in France] (1991), sugerindo que esse fenômeno teve lugar na França após o advento do controle de constitucionalidade. O próprio Stone reconhece que esse é um problema com maior probabilidade de acontecer em países como a França, que possui o controle de constitucionalidade abstrato no qual as contestações constitucionais tornam-se virtualmente o estágio final automático do processo legislativo, do que em países como os Estados Unidos, onde existe apenas o judicial review concreto (e, pode-se acrescentar, regras permanentes severas). Deve-se observar que o próprio Thayer, embora mais conhecido pela preocupação oposta, também endossava essa opinião. Veja Thayer, n. 122 supra, pp. 103-07. Tushnet denomina a essa questão "o problema da distorção política", veja n. 5 supra.

134 Como vimos, até o momento essa expectativa não foi satisfeita no Canadá. Eu comparo as três declarações de direitos quanto à probabilidade de garantir esse benefício, bem como os outros, na próxima seção.

135 Para exemplos recentes dessa tendência nos Estados Unidos, veja City of Boerne v. Flores, 521 U.S. 507 (1997) e Kimel v. Florida Board of Regents, 120 S.Ct. 631 (2000) (a Corte considera que, ao exercer seu poder de aplicar a Décima Quarta Emenda, o Congresso pode apenas aplicar a interpretação dada pela Corte à emenda e não a sua própria). Para comentários acadêmicos criticando que a posição da Corte vai além de seus limites, veja McConnell, "Instituições e interpretação: uma crítica de City of Boerne v. Flores" ["Institutions and Interpretation, A Critique of City of Boerne v. Flores"], 111 Harv. L. Rev. 153 (1997); Kramer, "Introdução: nós a Corte" ["Foreword: We the Court"] 115 Harv. L. Rev. 5 (2001); Coker \& Brudney, "Desrespeitando o Congresso" ["Dissing Congress,"] 100 Mich. L. Rev. 80 (2001); Barkow, "Mais supremo que a Corte" ["More Supreme Than Court"] 102 Colum. L. Rev. (no prelo). Para uma defesa geral do monopólio judicial da interpretação constitucional, veja Alexander \& Schauer, "Da interpretação constitucional extrajudicial" ["On Extrajudicial Constitutional Interpretation"], 110 Harv. L. Rev. 1359 (1997).

136 Esse, em particular, é o tema de Larry Kramer, id.

137 Todas as três declarações de direitos da comunidade britânica contêm tais limitações expressas. A Seção I da Carta canadense declara que seus direitos e liberdades estão garantidos e "sujeitos apenas aos limites 
razoáveis prescritos pela lei tais como podem ser justificados em uma sociedade livre e democrática". A Seção 5 da LDDNZ repete exatamente essa redação. A LDH copia a estratégia da CEDH que incorpora e que consiste em especificar limites individuais para direitos específicos, mais do que um limite geral para todos os direitos. A Constituição dos Estados Unidos, é claro, em geral não contém limites expressos, mas isso não quer dizer que os direitos sejam interpretados como absolutos.

138 A respeito da prevalência do equilíbrio no direito constitucional norte-americano moderno, veja Aleinikoff, "O direito constitucional na era do equilíbrio" ["Constitutional Law in the Age of Balancing"] 96 Yale L. J. 943 (1987).

$139 \mathrm{O}$ argumento geral de que a anulação pode resultar em maior proteção judicial aos direitos, pois os juízes terão menos medo de frustrar o processo democrático, foi apresentado no contexto canadense. Veja Dale Gibson, A lei da Carta: princípios gerais [The Law of the Charter: General Principles] 125-26 (1986). Uma outra maneira de fazer essa colocação é dizer que o novo modelo pode ajudar a resolver o problema da sub-aplicação judicial de normas constitucionais onde os tribunais têm a última palavra. Veja Sager, "Medida justa: o status jurídico de normas constitucionais sub-aplicadas" ["Fair Measure: the Legal Status of Underenforced Constitutional Norms"] 91 Harv. L. Rev. 1212 (1978).

140 Veja n. 39 supra.

141 Veja Cappelletti \& Cohen, n. 1 supra, pp. 80-83.

142 Assim, na Alemanha, as duas câmaras da legislativo, o Bundestag e o Bundesrat, selecionam, cada um, oito membros do Tribunal Constitucional (6 devem ser juízes federais). O Tribunal é dividido em dois conselhos (senates) de oito juízes. Na França, o Presidente, a Assembléia Nacional e o Senado selecionam, cada, três membros do Conselho Constitucional. De modo algo incomum, na Itália, o Presidente, o Parlamento e os tribunais mais elevados escolhem, cada, cinco membros para o Tribunal Constitucional.

143 Michael Perry sugeriu que esse procedimento pode ser importado com proveito para os Estados Unidos. Veja Perry, n. 5 supra, pp. 201.

144 A Espanha tem mandatos renováveis de nove anos e Portugal, de seis anos. Mesmo nos muitos países com mandatos fixos não renováveis, os juízes com frequência precisam ter carreiras pós-tribunal constitucional.

145 Veja Thayer, A origem e o alcance da doutrina norte-americana de Direito Constitucional ["The Origin and Scope of the American Doctrine of Constitutional Law"], 7 Harv. L. Rev. 17 (1893); Thayer, John Marshall, n. 122 supra.

146 Os Juízes Oliver Wendell Holmes e Felix Frankfurter foram os principais protegidos de Thayer na Suprema Corte.

147 A Constituição sueca permite a invalidação de uma lei apenas quando existe um conflito "óbvio ou aparente" (uppenbar) com a Constituição e a finlandesa, apenas quando há uma "controvérsia clara" (ilmeinen ristiriita). Veja Husa, n. 29 supra, pp. 361, 365.

148 Thayer, The Origin and Scope, n. 144 supra, pp. 144. Thayer alegou que essa regra não era invenção sua, mas, na verdade, a regra estabelecida na primeira metade do séc. XIX. Thayer aplicou essa regra apenas à revisão por tribunal federal de leis federais, pois isso envolvia as prerrogativas legiferantes de um poder coordenado do governo. Quando tribunais federais revisão leis estaduais, eles não estão lidando com um poder coordenado, mas são os representantes do governo federal superior e sua tarefa é traçar linhas de alocação do poder.

149 Veja Thayer, n. 122 supra.

150 Veja Bickel, The Least Dangerous Branch, n. 6 supra, pp. 111-99 (as "virtudes passivas" referem-se a numerosas formas procedimentais pelas quais os tribunais podem evitar responder a questões constitucionais: elas incluem as doutrinas da legitimidade, da perda do objeto (mootness, em inglês, segundo a qual só cabe ao judiciário decidir questões em que haja um objeto litigioso), da causa madura (ripeness, em inglês, de acordo com a qual o tribunal só admite recurso após esgotadas as outras vias administrativas e judiciais), a teoria da questão jurídica, da base independente e adequada da lei estadual, de responder apenas à questão mais estrita necessária para a decidir um processo e o poder discricionário de certiorari (descrito no dicionário de Maria Chaves como o recurso que cabe junto aos tribunais superiores contra uma decisão que viola a Constituição ou lei federal).

151 Thayer, n. 144 supra, pp. 149.

152 Após observar, na prática, o fracasso do mecanismo de anulação canadense para resolver como se esperava o problema da debilitação, Tushnet conclui que o minimalismo judicial thayeriano pode ser o único candidato plausível. Ele observa, contudo, que pode haver outras alternativas institucionais. Veja Tushent, n. 5 supra, pp. 299-301. Obviamente, a LDDNZ e a LDH são exemplos de tais alternativas.

153 De acordo com o Artigo III, Seção 2, cláusula 2, a jurisdição recursória da Suprema Corte deve sujeitar-se a "tais exceções conforme as Regulamentações que o Congresso possa fazer". 
154 Veja Tushnet, n. 5 supra, pp. 285-87.

155 Veja id.

156 Falando de maneira bastante ampla, essa foi a posição tomada por muitos países europeus que adotaram o controle de constitucionalidade após 1945 à luz de seus próprios, e de outros, registros recentes de direitos humanos. Contudo, observe que a tutela efetiva dos direitos pode revelar-se maior de acordo com o novo modelo porque os tribunais sentem-se menos constrangidos pelo medo de excluir pontos de vistas majoritários.

157 John Hart Ely, Democracia e desconfiança [Democracy and Distrust] (1971).

158 United States v. Carolene Products Co., 304 U.S. 144 (1938) (em uma nota de rodapé para seu voto nesse processo perante a Corte, o Juiz Stone sugeriu que a presunção normal de constitucionalidade que atribui ao Estado a regulamentação social e econômica pode ser inapropriada em ações em que "a legislação... restringe aqueles processos políticos que, de maneira ordinária, devem provocar a anulação da legislação indesejável”).

159 McCulloch v. Maryland, 4 Wheat. (17 U.S.) 316 (1819) ("Mas quando um Estado taxa as operações do governo dos Estados Unidos, ele age sobre instituições criadas não por seus próprios eleitores, mas pelo povo sobre o qual não reivindicam controle.").

160 Por exemplo, a Lei Fundamental alemã põe o valor substantivo da dignidade humana em primeiro lugar e no centro de seu esquema de valores constitucionais. Do ponto de vista (representativo) de um comentador, o Tribunal Constitucional alemão deixou claro que o Artigo 1(1) (que declara que "a dignidade do homem é inviolável. Respeitá-la e protegê-la é o dever de todas as autoridades do Estado") "expressa o mais alto valor da Lei Fundamental, informando o espírito e a substância de todo o documento". Veja Donald Kommers, A jurisprudência constitucional da República Federativa da Alemanha [The Constitutional Jurisprudence of the Federal Republic of Germany] 298 (2nd ed.; 1997).

161 Para Marshall, veja Marbury, n. 3 supra ("Os princípios, portanto, assim estabelecidos [pelo povo] são considerados fundamentais. E, uma vez que a autoridade da qual provêm é suprema (o povo), eles estão projetados para serem permanentes"). Para Hamilton, veja The Federalist 78 ("É muito mais racional supor que os tribunais foram projetados para serem um órgão intermediário entre o povo e o legislativo a fim de... manter a segunda dentro dos limites fixados para sua autoridade... a Constituição deve receber preferência em relação à lei, assim como a intenção do povo deve receber preferência em relação à intenção de seus agentes.").

162 A alegação é de que a melhor evidência do texto do povo que a Suprema Corte é obrigada a proteger é o texto que ele ratificou e/ou o entendimento contemporâneo do que as palavras que o povo ratificou significavam para ele.

163 Ackerman, We the People I, n. 17 supra.

164 Veja Waldron, n. 122 supra, pp. 255-81.

165 Veja nn. 124-26 supra.

166 Bickel, n. 6 supra, pp. 23-28.

167 Na verdade, um juízo a quo decidiu as mesmas questões de forma diferente. O Tribunal de Recursos do Quebec julgou que os usos gerais e padrão da anulação violavam o requisito de especificidade da Seção 33. Alliance des Professeurs de Montreal v. A.G. Quebec, [1985] C.A. 376, (1985) 21 D.L.R. (4th) 354. Essa decisão, que foi anulada em Ford, é discutida em Weinrib, n. 57 supra.

168 Veja Butler, n. 73 supra, pp. 336-38.

169 Id., p. 335-336, e n. 97 supra. Butler argumenta de maneira convincente que a margem de liberdade interpretativa dos tribunais, aqui, provém de explicações alternativas plausíveis da intenção legislativa, mais do que do desejo claro de sobrepujar um direito. Por exemplo, membros do parlamento podem discordar do Procurador-Geral quanto ao fato de uma medida proposta estar em conflito com um direito.

170 Apesar de as decisões judiciais de acordo com a LDDNZ terem sempre maior probabilidade de serem de alguma forma menos dramáticas do que aquelas emitidas de acordo com a Carta ou com a LDH, dado que aquelas serão decisões de interpretação jurídica, em vez de serem a invalidação de uma lei ou de declararem-na incompatível com um direito protegido.

\section{Submetido: CONVIDADO \\ Aprovado: CONVIDADO}

